\title{
Iodine emissions from the sea ice of the Weddell Sea
}

\author{
H. M. Atkinson ${ }^{1,2}$, R.-J. Huang ${ }^{3}$, R. Chance ${ }^{4, *}$, H. K. Roscoe ${ }^{1}$, C. Hughes ${ }^{2, * *}$, B. Davison ${ }^{5}$, A. Schönhardt ${ }^{6}$, \\ A. S. Mahajan ${ }^{7}$, A. Saiz-Lopez ${ }^{7}$, T. Hoffmann ${ }^{3}$, and P. S. Liss ${ }^{2}$ \\ ${ }^{1}$ British Antarctic Survey, Cambridge, UK \\ ${ }^{2}$ School of Environmental Science, University of East Anglia, Norwich, UK \\ ${ }^{3}$ Institute of Inorganic and Analytical Chemistry, Johannes Gutenberg University of Mainz, Mainz, Germany \\ ${ }^{4}$ Department of Chemistry, University of York, York, UK \\ ${ }^{5}$ Department of Environmental Sciences, Lancaster University, Lancaster, UK \\ ${ }^{6}$ IUP, University of Bremen, Bremen, Germany \\ ${ }^{7}$ Laboratory for Atmospheric and Climate Science, CSIC, Toledo, Spain \\ *now at: School of Environmental Science, University of East Anglia, Norwich, UK \\ *** now at: Department of Chemistry, University of York, York, UK
}

Correspondence to: H. K. Roscoe (hkro@bas.ac.uk)

Received: 7 March 2012 - Published in Atmos. Chem. Phys. Discuss.: 7 May 2012

Revised: 15 November 2012 - Accepted: 16 November 2012 - Published: 27 November 2012

\begin{abstract}
Iodine compounds were measured above, below and within the sea ice of the Weddell Sea during a cruise in 2009 , to make progress in elucidating the mechanism of local enhancement and volatilisation of iodine. $\mathrm{I}_{2}$ mixing ratios of up to $12.4 \mathrm{pptv}$ were measured $10 \mathrm{~m}$ above the sea ice, and up to $31 \mathrm{pptv}$ was observed above surface snow on the nearby Brunt Ice Shelf - large amounts. Atmospheric IO of up to 7 pptv was measured from the ship, and the average sum of $\mathrm{HOI}$ and ICl was $1.9 \mathrm{pptv}$. These measurements confirm the Weddell Sea as an iodine hotspot. Average atmospheric concentrations of $\mathrm{CH}_{3} \mathrm{I}, \mathrm{C}_{2} \mathrm{H}_{5} \mathrm{I}, \mathrm{CH}_{2} \mathrm{ICl}, 2-\mathrm{C}_{3} \mathrm{H}_{7} \mathrm{I}, \mathrm{CH}_{2} \mathrm{IBr}$ and $1-\mathrm{C}_{3} \mathrm{H}_{7} \mathrm{I}$ were each $0.2 \mathrm{pptv}$ or less. On the Brunt Ice Shelf, enhanced concentrations of $\mathrm{CH}_{3} \mathrm{I}$ and $\mathrm{C}_{2} \mathrm{H}_{5} \mathrm{I}$ (up to 0.5 and 1 pptv respectively) were observed in firn air, with a diurnal profile that suggests the snow may be a source. In the sea ice brine, iodocarbons concentrations were over 10 times those of the sea water below. The sum of iodide + iodate was depleted in sea ice samples, suggesting some missing iodine chemistry. Flux calculations suggest $\mathrm{I}_{2}$ dominates the iodine atom flux to the atmosphere, but models cannot reconcile the observations and suggest either a missing iodine source or other deficiencies in our understanding of iodine chemistry. The observation of new particle formation, consistent with the model predictions, strongly suggests an iodine source. This combined study of iodine compounds is the first of its kind in this unique region of sea ice rich in biology and rich in iodine chemistry.
\end{abstract}

\section{Introduction}

The presence of iodine oxides, formed via reactions of iodine compounds with ozone that may contribute to ozone depletion events (Chameides and Davis, 1980), may also lead to new particle formation (O'Dowd et al., 2002). Growth of such particles would increase the number density of cloud condensation nuclei and so the albedo of clouds, thereby cooling regionally (Slingo, 1990). Given the large amounts of IO observed by a ground-based spectrometer near the Weddell Sea (Saiz-Lopez et al., 2007), understanding the local enhancement of atmospheric iodine is an essential part of understanding control of regional climate and chemistry.

Satellite measurements (Schönhardt et al., 2008) showed that such large amounts of IO exist over much of the sea ice of the Weddell Sea. Hence an iodine-selective mechanism must exist that concentrates and volatilises iodine from the ocean, but does not concentrate bromine - bromide is over 1000 times more abundant than iodide in seawater, whereas atmospheric concentrations of IO near the Weddell Sea are similar to those of BrO (Saiz-Lopez et al., 2007). Release of bromine into the atmosphere occurs via heterogeneous reactions with bromide, enhanced by brine formation during freezing of sea water (Barrie et al., 1988; Vogt et al., 1996). Iodine requires a more efficient mechanism of enhancement.

One such mechanism may be the emission of volatile iodine from sea-ice diatoms. The sea ice of the Weddell Sea 
is characterised by high porosity and high biological activity (Garrison and Buck, 1989), and by gap layers rich in diatoms some 10 or $20 \mathrm{~cm}$ below the ice surface (Haas et al., 2001; Ackley et al., 2008; Kattner et al., 2004), some of which are a source of iodocarbons (Moore et al., 1996; Tokarczyk and Moore, 1994). Fogelqvist and Tanhua (1995) observed enhanced concentrations of iodocarbons in sea ice pore water in the Weddell Sea. Previous measurements close to the ice edge of the Southern Ocean (Carpenter et al., 2007) found high concentrations of halocarbons in surface waters from ice melt. Previous measurements of polar iodocarbons are listed in Supplement Tables S1 and S2. Saiz-Lopez and Boxe (2008) proposed that sea ice diatoms could be responsible for $\mathrm{I}_{2}$ emission as the precursor of the observed IO in coastal Antarctica. Diatoms can accumulate iodide (de la Cuesta and Manley, 2009), release HOI (Hill and Manley, 2009) and convert iodate to iodide (Chance et al., 2007).

Whilst biological production is thought to be the dominant source of iodocarbons, alternative pathways have been proposed, involving light (Spokes and Liss, 1996), humic material (Carpenter et al., 2005) and ozone (Martino et al., 2009). The freezing of sea water could release inorganic iodine (O'Driscoll et al., 2006), involving the nitrite and iodide present in sea salt: protonation of $\mathrm{HONO}$ by $\mathrm{H}^{+}$ions, rejected from the ice phase and concentrated in liquid micropockets, leads to $\mathrm{H}_{2} \mathrm{ONO}^{+}$which may then react with $\mathrm{I}^{-}$to release $\mathrm{I}_{2}$ and NO. This reaction, which has previously been known to occur in weakly acidic solutions, may therefore occur in neutral solutions which undergo a freeze thaw cycle.

Field measurements of volatile iodine compounds in sea water covered in ice are rare, most have been at temperate coasts, where macroalgae have been shown to be a strong source (Carpenter et al., 1999; Furneaux et al., 2010; Huang et al., 2010a). At one such location in Ireland, a link was shown between iodocarbons, IO and new particle bursts, at low tide when macroalgae were exposed (Allen et al., 1999; Carpenter et al., 1999). $I_{2}$ has been proposed as the most important precursor for marine coastal new particle formation (Huang et al., 2010b; Mahajan et al., 2011; McFiggans et al., 2004; Saiz-Lopez and Plane, 2004; Saiz-Lopez et al., 2007). HOI and ICl (collectively termed Activated Iodine Compounds, AIC) were also detected by Huang and Hoffman (2009) with maximum concentrations of $30 \mathrm{pptv}$ at night and 6 pptv during the day.

If diatoms capable of accumulating iodide and releasing iodine compounds reside in Southern Ocean sea ice, and the sea ice is porous enough to allow trace gases to escape, they would be a source of atmospheric iodine oxides. In this paper, we investigate several steps in this process:

a. Organic and inorganic iodine compounds were measured.

b. Chlorophyll $a(\mathrm{Chl} a)$ was measured, as an indication of algae distribution in the ice. c. Physical properties of the ice were used to determine the continuity of the brine channel network that provides a path to the atmosphere.

d. IO and new particle formation were measured.

e. Saturation anomalies, flux calculations and modelling were used to interpret the measurements.

This is the first combined in situ Antarctic study of organic and inorganic iodine compounds in sea water, ice and air, together with their resultant IO and new particles.

\section{The field campaign, materials and methods}

Measurements were made from 28 January to 5 March 2009 on the ice-strengthened RRS Ernest Shackleton (cruise ES033) sailing from Stanley in the Falkland Islands $\left(51.6^{\circ} \mathrm{S}\right.$, $\left.57.6^{\circ} \mathrm{W}\right)$ via Signy $\left(60.7^{\circ} \mathrm{S}, 45.6^{\circ} \mathrm{W}\right)$, to the ice covered Weddell Sea where sea-ice cores were collected between 5 and 14 February. Between 19 and 22 February the ship was moored against the Brunt Ice Shelf $\left(75.4^{\circ} \mathrm{S}, 26.8^{\circ} \mathrm{W}\right)$, on which an experimental site was set up where air was nearcontinuously monitored. The ship then returned via Signy to Stanley. Seawater and air were sampled at irregular intervals throughout. Table 1 gives a summary of the measurements, and Fig. 1 shows the ship's track.

\subsection{Sample collection}

Air was sampled from the forecastle $10 \mathrm{~m}$ above sea level, via Tygon tubing to a pump, pressure gauge, mass flow controller and data logger below the bow. The flow rate was regularly checked with a flow meter on inlets of the Markes sorbent tube (halocarbons) and the denuder tube ( $\mathrm{I}_{2}$ and AIC). These were deployed for $40 \mathrm{~min}$ at a flow rate of $25 \mathrm{~mL} \mathrm{~min}^{-1}$, and $3 \mathrm{~h}$ at the same time each day at a rate of $500 \mathrm{~mL} \mathrm{~min}^{-1}$, respectively.

Ice cores were collected with a $1 \mathrm{~m}$ long, $9 \mathrm{~cm}$ diameter corer, within $50 \mathrm{~m}$ of the ship. Ice was between 80 and $180 \mathrm{~cm}$ thick, and the cores represent the full thickness of the ice, except the first on 5 February that was only the top metre of thicker ice. Cores were immediately cut into $10 \mathrm{~cm}$ or $3 \mathrm{~cm}$ long sections in order that vertical profiles of concentrations could be ascertained. The middle of each section was sub-sampled with a custom stainless steel mini-corer with dimensions to match those of a $100 \mathrm{~mL}$ gas-tight syringe. It is always a problem to retain the brine when sampling a sea ice core, we relied on speed. Each mini-core was immediately transferred to a syringe and left to melt at room temperature in the dark (we acknowledge cell rupture could have occurred during ice melt). This method limited escape of the compounds as much as possible before the ice was placed in the syringe. Four ice cores were collected during the campaign, from which a total of 43 sub-samples were analysed. 


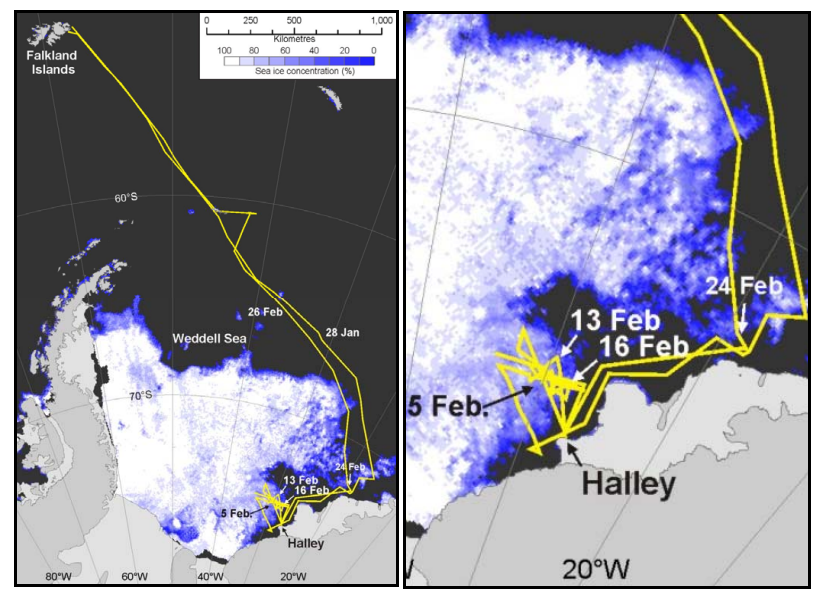

Fig. 1. Cruise path of ES033 in the Southern Ocean and Weddell Sea, and ice cover on 21 February 2011. Ice cores were collected between 5 and 13 February. Between 19 and 22 February the ice shelf experiment was set up close to Halley, where the ship was moored.

Diatom-rich ice (DRI) was collected on three occasions - a small boat was used to collect ice samples where discolouration due to the presence of diatoms could clearly be seen (Fig. 2). The presence of ice algae was later confirmed by microscopy. By leaning over the side of the boat, a total of 12 gas-tight syringes were filled with ice using a stainless steel scoop, and left to melt in the dark at room temperature. The DRI samples were in contact with water from an adjacent lead. They contained a large proportion of brine, hence were assumed to be very porous.

Underway seawater (USW) was sampled from the ship's $6 \mathrm{~m}$ depth supply, at irregular intervals during the campaign. Samples were taken with a $100 \mathrm{~mL}$ gas-tight syringe directly from the pump outlet on the ship. This ensured limited exposure to air. The water was run for a few minutes before sampling, after which no bubbles were visible.

\subsection{Measurement methods}

Volatile inorganic iodine was sampled using a coupled diffusion denuder system (Huang and Hoffman, 2009). Briefly, 1,3,5-trimethoxybenzene (1,3,5-TMB)-coated brown borosilicate glass $(50 \mathrm{~cm}$ length $\times 6 \mathrm{~mm}$ i.d. $)$ tubes were used for AIC, and $\alpha$-cyclodextrin $/{ }^{129} \mathrm{I}^{-}\left(\alpha-\mathrm{CD} /{ }^{129} \mathrm{I}^{-}\right)$-coated tubes further downstream for $\mathrm{I}_{2}$. A prior uncoated glass tube ( $30 \mathrm{~cm}$ length $\times 6 \mathrm{~mm}$ i.d.) generated laminar flow. The coupled tubes were mounted vertically on the foremast $10 \mathrm{~m}$ above sea level connected to a pump and mass flow controller. Air was sampled for $3 \mathrm{~h}$ at a rate of $500 \mathrm{~mL} \mathrm{~min}^{-1}$, around noon once each day whilst on the ship, but several times a day during the ice shelf experiment (see Sect. 3.6). After sampling, tubes were sealed with polypropylene endcaps, transported and stored at $-20^{\circ} \mathrm{C}$, and analysed by
Table 1. Measurements made during cruise ES033. See Sect. 2.2 for details of apparatus.

\begin{tabular}{lll}
\hline Analyte & Medium & Technique \\
\hline $\mathrm{I}_{2}, \mathrm{HOI}$ and ICl & Air & Denuder tubes then GCMS \\
IO & Air & Mini-MAX-DOAS \\
Halocarbons & Air, water and ice & GCMS \\
Iodide & Water and ice & Cyclic voltammetry \\
Iodate & Water and ice & Spectrophotometry \\
Chl $a$ & Water and ice & Fluorometry \\
Brine volume & Ice & Temperature and salinity \\
& & measurements \\
Particles & Air & Particle counter \\
Ozone & Air & Ozone monitor \\
\hline
\end{tabular}

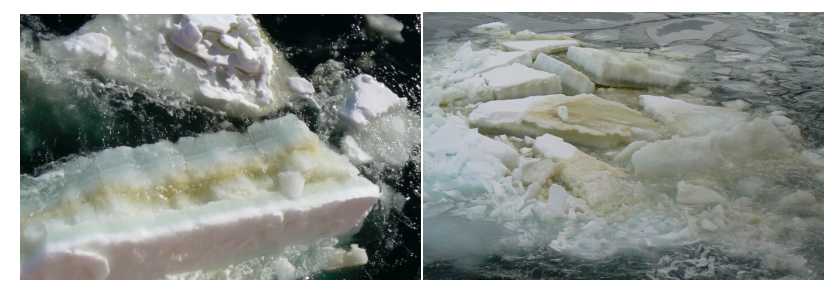

Fig. 2. Ice floes broken by the ship's passage through sea ice of thickness $0.2 \mathrm{~m}$ in the Weddell Sea, where diatom bands are clearly visible about $0.1 \mathrm{~m}$ below the surface of the ice.

GCMS at University of Mainz within 6 months. Two blanks of each were prepared in a similar manner to the sampling tubes, but without drawing any air through them: fresh examples of all three tubes used to make a sample $(1,3,5-$ TMB coated brown borosilicate glass tube, the coated denuder tube, and the glass tube at the inlet to ensure a laminar flow) were used to create a blank; they were removed from the freezer, polypropylene end-caps removed, connected together with short sections of teflon tubing, and a polypropylene end-cap was placed over each end of the assembly; the assembly was carried to the front of the ship, and back again; the three tubes were then disconnected, the polypropylene end-caps were replaced over the end of each tube, sealed with PTFE tape, and placed back in the freezer. They were transported to Mainz for analysis with the sample tubes, with results 0.93 and 1.16 pptv for blank $\mathrm{I}_{2}$, and 0.16 and $0.25 \mathrm{pptv}$ for blank AIC; mean blank values were subtracted from the values for atmospheric samples. Triplicate analyses on the same atmospheric sample tube gave a standard deviation of $12 \%$ or less for AIC and $6 \%$ or less for $\mathrm{I}_{2}$. The limits of detection of previous similar measurements for our $90 \mathrm{~L}$ sample volume were 0.03 pptv for AIC, and 0.1 pptv for $\mathrm{I}_{2}$; studies by Huang and Hoffman (2009) showed that linearity was better than $2 \%$ for $\mathrm{I}_{2}$ and $5 \%$ for AIC, and that collection efficiency at our flow rate was better than $98 \%$ for $\mathrm{I}_{2}$ and $97 \%$ for AIC (their Figs. 2 and 3).

IO was measured by a Multiple Axis (vertically scanning) UV-visible Differential Optical Absorption Spectrometer 
(MAX-DOAS, Hönninger and Platt, 2002). The miniature instrument (Hoffman-Heidelberg design) was mounted on the bridge looking out of a window from $15 \mathrm{~m}$ above sea level. It measured from 337 to $481 \mathrm{~nm}$ with a spectral resolution of about $0.7 \mathrm{~nm}$. IO was analysed from 409 to $474 \mathrm{~nm}$ by the WinDOAS program using various reference spectra near local noon at $50^{\circ}$ elevation. Median slant amounts during each day with prolonged sunny periods were found, at elevation angles of $4^{\circ}, 8^{\circ}, 15^{\circ}$ and $50^{\circ}$. The $50^{\circ}$ value was then subtracted from those at $4^{\circ}, 8^{\circ}$ and $15^{\circ}$, and divided by differences in air mass factors (AMFs) to derive vertical amounts. Errors on slant columns given by the spectral fitting program mostly varied between 3 and $8 \times 10^{12}$ molec $\mathrm{cm}^{-2}$, though a few values are as large as $12 \times 10^{12} \mathrm{molec} \mathrm{cm}^{-2}$. The standard deviation of IO slant columns at each elevation on each day mostly varied between 3 and $6 \times 10^{12}$ molec cm $^{-2}$, though a few values are as large as $30 \times 10^{12}$ molec cm $^{-2}$. Hence there is some consistency between the spectral fit and scatter of the points, except there are some occasional outliers on some days, hence our decision to use daily medians rather than daily means. Dividing by the mean AMF results in an error on the individual vertical columns of 0.5 to $1 \times 10^{12}$ molec $\mathrm{cm}^{-2}$. The number of elevation scans on each day ranged from 4 to 48 , with a mean value of 19 . It is unclear if the error in vertical column would reduce by the averaging, but if so it would then be mostly less than $0.2 \times 10^{12}$ molec $\mathrm{cm}^{-2}$. Mixing ratios were then calculated assuming that all the IO resided in the boundary layer over the sea ice, i.e. assuming that the lifetime of the source compounds of IO is long enough for them to be well mixed in the boundary layer. Following Renfrew and King (2000), we assumed a boundary layer of thickness $200 \pm 50 \mathrm{~m}$. The derived mixing ratios then take on an error proportional to this range of thickness, i.e. $\pm 25 \%$.

IO columns were also measured by SCIAMACHY (Schoenhardt et al., 2008) on board Envisat during the campaign. The technique measures the absorption by IO of sunlight backscattered from the atmosphere with a UV-Vis-NIR spectrometer. The stability of the space-borne spectrometer is necessarily much better than that of our ship-board MAX-DOAS, and the spectral analysis is very similar, but the AMFs are much smaller when viewed from space.

Melted ice and water samples for $\mathrm{Chl} a$, iodide and iodate analysis were filtered through a $47 \mu \mathrm{m}$ Whatman GF/F filter paper, the filtered water was stored at $-20^{\circ} \mathrm{C}$ on the ship and transported to UK for analysis. Water samples for halocarbon analysis were filtered through $47 \mu \mathrm{m}$ Whatman GF/F filter papers directly into a glass tube, in which the halocarbons were extracted by purging for $10 \mathrm{~min}$ with nitrogen at $95 \mathrm{~mL} \mathrm{~min}^{-1}$ onto a Markes sorbent tube; these purge rates were used successfully by Hughes et al. $(2008,2010)$ and Hopkins et al. (2012); extraction efficiencies were measured to be 1 for $\mathrm{CH} 3 \mathrm{I}$ and $\mathrm{C} 2 \mathrm{H} 5 \mathrm{I}, 0.5$ for CHBr3, 0.6 for other halocarbons; these were applied to all data cited below. The

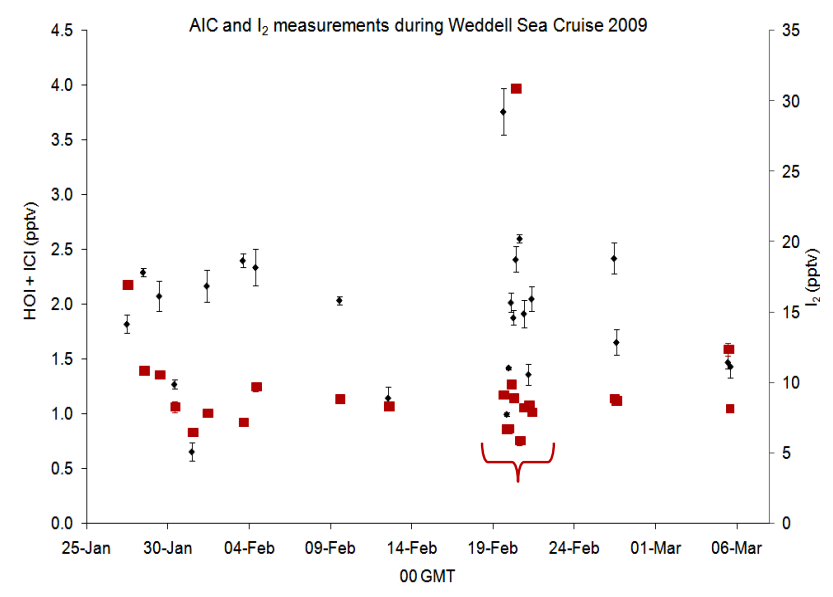

Fig. 3. Atmospheric AIC (HOI $+\mathrm{ICl}$, black diamonds) and $\mathrm{I}_{2}$ (red squares) concentrations during the field campaign, measurements were made on board the ship, except those denoted by the red downward-pointing bracket that were made on the Brunt Ice Shelf. Each point denotes a $3 \mathrm{~h}$ sample, the mid-sampling time is shown. Average values of triplicate samples are shown, error bars are 1 standard deviation.

filter papers were wrapped in aluminium foil and stored at $-80^{\circ} \mathrm{C}$ on the ship for Chl $a$ analysis back in UK.

Halocarbon analysis was carried out on the ship with a Markes Unity thermal desorption unit and UltrA autosampler connected to an Agilent gas chromatograph-mass spectrometer (GCMS). The GC was fitted with a $60 \mathrm{~m}$ capillary column (DB-VRX, J\&W) and the MS operated in the electron impact ionization mode. Data acquisition was performed in selected ion monitoring mode. Following desorption, compounds were refocused on a cold trap at $10^{\circ} \mathrm{C}$, which was then heated to $290^{\circ} \mathrm{C}$ to transfer the compounds into the GC using helium at a flow rate of $2 \mathrm{~mL} \mathrm{~min}^{-1}$. The GC oven was held at $36{ }^{\circ} \mathrm{C}$ for $5 \mathrm{~min}$ at the start of the run, then raised to $200^{\circ} \mathrm{C}$ over $10 \mathrm{~min}$, held there for $2 \mathrm{~min}$, then heated rapidly to $240^{\circ} \mathrm{C}$. In total 9 halocarbons were measured, listed in Table 2. Their limits of detection improved during the course of the campaign, but $\mathrm{CH}_{2} \mathrm{I}_{2}$ could not be measured due to a contamination problem. Liquid calibration standards (Sigma) dissolved in methanol were prepared in the UK and kept at $-20^{\circ} \mathrm{C}$ until being injected into pre-purged seawater at the start and end of the campaign. $R^{2}$ values for all calibration curves were above 0.96 . To extrapolate from water concentrations to mixing ratios in air, extraction efficiencies of the halocarbons in water were calculated. The sensitivity was monitored and accounted for during the campaign by injecting each sample with a known concentration of deuterated 1-iodopropane and deuterated methyl iodide dissolved in methanol, which was checked for contamination at regular intervals. Measurement precision, determined by the range of duplicate water samples, was between $1 \%$ and $14 \%$. 
Table 2. Halocarbons measured by GCMS, showing mass/charge ratio, retention time, and limit of detection (LoD). There were 55 ice samples, 37 water samples and 99 air samples. Results for ice and water samples are in pM, results for air samples are in pptv. The LoD result is the LoD at the start of the campaign. Average and maximum values for ice and water samples are normalised to brine volume and rationalised to salinity (see Sect. 3) - for comparison with their LoDs, the observed ice and water results are typically $1 / 8$ the average and maximum results reported here.

\begin{tabular}{|c|c|c|c|c|c|c|}
\hline Compound & $\begin{array}{l}\text { Mass/ } \\
\text { charge }\end{array}$ & $\begin{array}{l}\text { Retention } \\
\text { time } \\
\text { (minutes) }\end{array}$ & $\begin{array}{l}\text { Sample } \\
\text { type }\end{array}$ & $\begin{array}{l}\text { Limit of } \\
\text { detection }\end{array}$ & Average & Maximum \\
\hline \multirow[t]{3}{*}{$\mathrm{CH}_{3} \mathrm{I}$} & 142 & 6.4 & Ice & 0.15 & 4.8 & 149 \\
\hline & & & Water & 0.15 & 0.4 & 1.4 \\
\hline & & & Air & 0.15 & 0.1 & 0.5 \\
\hline \multirow[t]{3}{*}{$\mathrm{C}_{2} \mathrm{H}_{5} \mathrm{I}$} & 156 & 8.5 & Ice & 0.28 & 31 & 739 \\
\hline & & & Water & 0.28 & 1.2 & 6.5 \\
\hline & & & Air & 0.27 & 0.2 & 2.1 \\
\hline \multirow[t]{3}{*}{$\mathrm{CHBr}_{3}$} & 173 & 12.8 & Ice & 1.82 & 270 & 6850 \\
\hline & & & Water & 1.82 & 24 & 71 \\
\hline & & & Air & 0.89 & 3.3 & 41 \\
\hline \multirow[t]{3}{*}{$\mathrm{CH}_{2} \mathrm{ICl}$} & 176 & 10.4 & Ice & 0.18 & 9.6 & 455 \\
\hline & & & Water & 0.18 & 0.2 & 1.1 \\
\hline & & & Air & 0.11 & 0.07 & 4.3 \\
\hline \multirow[t]{3}{*}{$2-\mathrm{C}_{3} \mathrm{H}_{7} \mathrm{I}$} & 170 & 9.6 & Ice & 0.34 & 9.9 & 311 \\
\hline & & & Water & 0.34 & 0.4 & 1.1 \\
\hline & & & Air & 0.20 & 0.03 & 0.6 \\
\hline \multirow{3}{*}{$\mathrm{CH}_{2} \mathrm{IBr}$} & 222 & 11.9 & Ice & 0.12 & 6.3 & 406 \\
\hline & & & Water & 0.12 & $<\mathrm{LoD}$ & $<\mathrm{LoD}$ \\
\hline & & & Air & 0.29 & 0.03 & 1.0 \\
\hline \multirow[t]{3}{*}{$\mathrm{CHBr}_{2} \mathrm{Cl}$} & 129 & 11.6 & Ice & 0.83 & 6.7 & 49 \\
\hline & & & Water & 0.83 & 0.9 & 3.4 \\
\hline & & & Air & 0.49 & 0.4 & 5.7 \\
\hline \multirow[t]{3}{*}{$1-\mathrm{C}_{3} \mathrm{H}_{7} \mathrm{I}$} & 170 & 10.4 & Ice & 0.33 & 14 & 258 \\
\hline & & & Water & 0.33 & 0.9 & 2.9 \\
\hline & & & Air & 0.19 & 0.07 & 2.9 \\
\hline \multirow[t]{3}{*}{$\mathrm{CH}_{2} \mathrm{Br}_{2}$} & 174 & 10.0 & Ice & 0.77 & 22 & 1270 \\
\hline & & & Water & 0.77 & 2.6 & 9.6 \\
\hline & & & Air & 0.45 & 1.1 & 5.3 \\
\hline
\end{tabular}

Iodide $\left(\mathrm{I}^{-}\right)$and iodate $\left(\mathrm{IO}_{3}^{-}\right)$concentrations were measured in UK within 9 months of the campaign. The water samples were frozen in plastic tubes, and transported and stored at $-20^{\circ} \mathrm{C}$. Iodide concentrations were measured using cathodic stripping square wave voltammetry (Luther et al., 1988). An Eco-chemie $\mu$ Autolab Type II voltammeter was used with an IME 663 control unit and a Metrohm 663 VA hanging mercury drop electrode. Iodate concentrations were measured spectrophotometrically (Jickells et al., 1988).

$\mathrm{Chl}-a$ was extracted in darkness at $4{ }^{\circ} \mathrm{C}$ in $10 \mathrm{~mL}$ of $90 \%$ acetone buffered with $\mathrm{MgCO}_{3}$. It was measured using a Turner AU-10 fluorometer with red-sensitive photomultiplier (10-AU-600), blue lamp (10-089), blue excitation filter $(340-500 \mathrm{~nm})$ and red emission filter $(>665 \mathrm{~nm})$. Concen- trations were corrected for interference from phaeophytin-a by measuring fluorescence before and after acidification with $8 \% \mathrm{HCl}$. Calibration used a pure $\mathrm{Chl} a$ standard (Chl $a$ from Anacystis nidulans - $1 \mathrm{mg}$ diluted in $90 \%$ buffered acetone, Sigma-Aldrich), whose concentration was determined spectrophotometrically.

Particles were counted with two Grimm 5.401 particle counters either of which could be attached to a differential mobility analyser to give the size spectrum. The lower cutoff of the particle counters when operated alone was $5 \mathrm{~nm}$ diameter. Flow rates were $3 \mathrm{~L} \mathrm{~min}^{-1}$ for the sheath inlet and $3 \mathrm{~L} \mathrm{~min}^{-1}$ for the sampling tubes, organised to be isokinetic. Sampling efficiencies depend on the minimum bend radius of the tubing in the installation; previous calibrations showed 
sampling efficiencies of unity for this style of installation up to $1000 \mathrm{~nm}$ diameter. The analyser had 44 size bins starting at $9.8 \mathrm{~nm}$ mean diameter, with widths of $10 \%$ of their value up to $100 \mathrm{~nm}$, rising to $15 \%$ at $875 \mathrm{~nm}$ (see Table S3). Ozone was measured using a 2B Technology dual beam 205 ozone analyser. They were each mounted in the ship's conning tower with inlet on its starboard side, well above the deck. Inlets were via inverted funnels to prevent water ingress.

Wind speed and direction were recorded with a Kestrel 4500 when the ship was sailing, compensated for ship speed and heading from the ship's automated logger. The Kestrel sensor was located on a small elevated deck just below the conning tower. When the ship was moored, wind speed and direction were from Halley, $12 \mathrm{~km}$ to the SSW.

In the ice cores, the temperature (handheld temperature probe) and bulk salinity (Hach sensION5 ISFET conductivity meter with internal temperature correction, accuracy $0.1 \mathrm{psu}$ ) of the ice were measured. From them, brine volume fraction $V_{\mathrm{b}}(\% \circ)$ was calculated using the empirical equations of Frankenstein and Garner (1967):

$V_{\mathrm{b}}=S_{i}((-45.917 / \theta)+0.930)$ when $-8.2 \leq \theta \geq-2.0^{\circ} \mathrm{C}$

$V_{\mathrm{b}}=S_{i}((-43.975 / \theta)+1.189)$ when $-22.9 \leq \theta \geq-8.2^{\circ} \mathrm{C}$

where $S_{i}$ is bulk salinity in psu, and $\theta$ is temperature in ${ }^{\circ} \mathrm{C}$.

\subsection{Ice shelf experiment}

This experiment was set up about $20 \mathrm{~m}$ from the edge of the ice shelf. Denuder tubes were deployed to sample air $1 \mathrm{~m}$ above the snow. A nearby tent housed a battery and pump, connected to the denuder tubes via Teflon tubing. Near-continuous air samples were taken for 3 days. Air at the same height was also sampled for halocarbons at $3 \mathrm{~h}$ intervals by drawing air through a sorbent tube connected to a gas-tight syringe with a piece of Tygon tubing. Halocarbons in interstitial air in the snow were also measured, using a Teflon-lined plastic tube, $0.6 \mathrm{~m}$ long, $0.1 \mathrm{~m}$ diameter, pushed $20 \mathrm{~cm}$ into the snow with a valve at the top, through which air was drawn with a gas-tight syringe. Syringes were capped and taken to the ship for analysis.

\subsection{Saturation anomalies, flux calculations and modelling of data}

Saturation anomalies, defined as the departure from the expected equilibrium between trace gas concentration in surface seawater and in the atmosphere above, were calculated via Eq. (3) (Sander, 1999):

Saturation anomaly $(\%)=100 \times\left(C_{\mathrm{w}}-C_{\mathrm{a}} / H\right) /\left(C_{\mathrm{a}} / H\right)$

where $C_{\mathrm{w}}$ is the concentration in seawater, $C_{\mathrm{a}}$ in the atmosphere, and $H$ is the Henry's law constant.
Flux was calculated as detailed in Johnson (2010). Briefly, the equation $F=K_{\mathrm{w}}\left(C_{\mathrm{a}} / H-C_{\mathrm{w}}\right)$ was used where $F$ is the flux, $K_{\mathrm{W}}$ is the transfer velocity, and other terms as in Eq. (3). Transfer velocities depend on wind speed, salinity and water temperature. Fluxes were salinity rationalised instead of the more accurate brine-volume corrected (see Sect. 3), however the mean difference between the two is less than $10 \%$.

To calculate the flux of iodine necessary to reproduce observed $\mathrm{I}_{2}$ and $\mathrm{IO}$ we used the one-dimensional photochemistry and transport Tropospheric Halogen Chemistry Model (THAMO) (Saiz-Lopez et al., 2008). It was run at a vertical resolution of $1 \mathrm{~m}$, up to a boundary layer height of $200 \mathrm{~m}$ (Renfrew and King, 2000). The vertical transport in the model was constrained using wind shear calculated from observed wind speed, and a surface roughness length of $5 \times 10^{-5} \mathrm{~m}$ set according to long-term observations at Halley (King and Anderson, 1994). The eddy diffusion coefficient $\left(K_{z}\right)$ thereby increased from $8 \times 10^{2} \mathrm{~cm}^{2} \mathrm{~s}^{-1}$ at $1 \mathrm{~m}$ to a maximum of $3.2 \times 10^{5} \mathrm{~cm}^{2} \mathrm{~s}^{-1}$ at $32 \mathrm{~m}$. In addition to photochemical, gas-phase and heterogeneous reactions, THAMO treats the formation of new iodine oxide particles using coagulation of iodine oxides and uptake of condensable vapours (Mahajan et al., 2010).

\section{Results}

\subsection{Inorganic iodine compounds}

AIC and $\mathrm{I}_{2}$ mixing ratios remained reasonably constant with time (Fig. 3) apart from separate peaks in single samples of each during the ice shelf experiment. Concentrations of inorganic iodine (Table 3) are two orders of magnitude larger than those of iodocarbons (Table 2). Together with their much shorter photolytic lifetimes, this suggests that inorganic iodine is the dominant source of IO in the atmosphere above the Weddell Sea.

\subsection{IO mixing ratios}

Figures 4 and 5 show IO measured by the ship-board MAXDOAS and the satellite-based SCIAMACHY. These are large amounts, emphasising the nature of the Weddell Sea as an iodine hotspot. Vertical columns from the ship were up to $3.8 \times 10^{12}$ molec $\mathrm{cm}^{-2}$, somewhat larger than the satellite

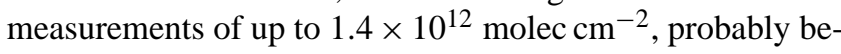
cause (a) the ship was closer to the likely sources, and (b) the viewing geometries were different - over open water the satellite instrument struggles to see sunlight scattered from the lowest level of the atmosphere where much of the IO is located, and the signal over open water is much smaller than over ice so enhanced IO above open water leads may only be partly seen. Figures 5 and 6 reveal striking similarity between IO and average ice area in the Weddell Sea. 
Table 3. Measurements other than halocarbons during the Weddell Sea cruise.

\begin{tabular}{llllll}
\hline Measurement & Number of samples & LoD & Average & Max & Min \\
\hline $\mathrm{I}_{2}$ in air $(\mathrm{pptv})$ & $24 \times 3 \mathrm{~h}$ & 0.095 & 5.8 & 30.9 & 3.9 \\
AIC in air $(\mathrm{pptv})$ & $24 \times 3 \mathrm{~h}$ & 0.029 & 1.9 & 3.8 & 0.7 \\
Chl $a$ in ice $\left(\mu \mathrm{g}^{-1}\right)$ & 22 & 0.01 & 2.27 & 9.03 & 0.004 \\
$\mathrm{Chl} a$ in water $\left(\mu \mathrm{g}^{-1}\right)$ & 4 & 0.01 & 0.14 & 0.22 & 0.05 \\
Iodide in ice $(\mathrm{nM})$ & 10 & 0.08 & 10.0 & 38.0 & 3.9 \\
Iodide in water $(\mathrm{nM})$ & 2 & 0.08 & 61.3 & 97.6 & 25.1 \\
Iodate in ice $(\mathrm{nM})$ & 10 & 30 & 19.1 & 50.0 & 5.5 \\
Iodate in water $(\mathrm{nM})$ & 2 & 30 & 358 & 364 & 351 \\
IO in air $(\mathrm{pptv})$ & 36 days & 0.3 & 5.1 & 6.6 & 2.7 \\
Particles in air $\left(\mathrm{cm}^{-3}\right)$ & every 7 min (spectra) \& 1 min (total) & 5 & - & $10^{5}$ & 5 \\
\hline
\end{tabular}

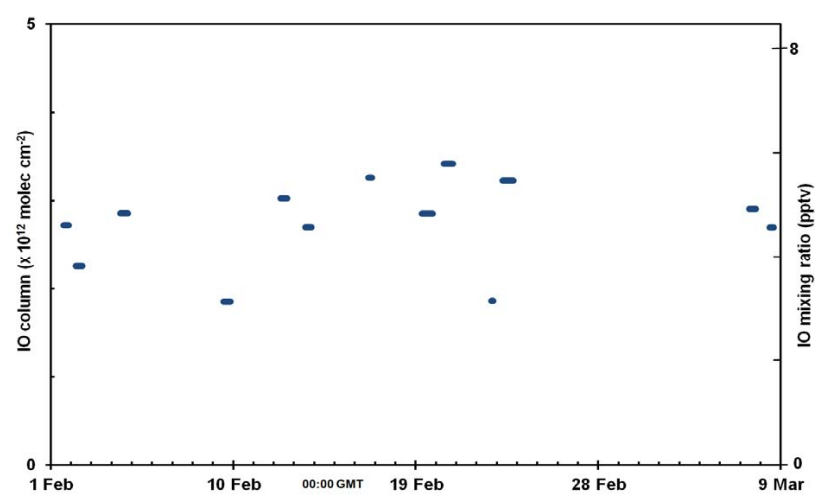

Fig. 4. IO vertical column densities above the sea ice of the Weddell Sea, and their equivalent mixing ratios assuming the IO is well mixed within a boundary layer of height $200 \mathrm{~m}$ (see Sect. 2.2). These values are medians of each sunny day or part-day.

\subsection{Halocarbons, Chlorophyll $a$ and brine volume}

As we assume that the biological and chemical activity of interest is occurring in the liquid phase of sea ice, values reported for bulk ice samples have been normalised to sea ice brine volume, and rationalised to salinity (multiplied by the ratio of sea water to brine salinities), via Eq. (4):

$$
R[x]_{\text {brine }}=\left(\left([x]_{\text {measured }} / V_{\mathrm{b}}\right) / S_{\text {brine }}\right) S_{\text {ref }}
$$

where $R[x]_{\text {brine }}$ is the normalised and salinity rationalised concentration of compound $x,[x]_{\text {measured }}$ is the concentration of analyte $x$ measured in the bulk ice sample, $V_{\mathrm{b}}$ is brine volume fraction, $S_{\text {brine }}$ is the salinity of the brine and $S_{\text {ref }}$ is the salinity of the underlying seawater $(33 \%)$. For our samples where $S_{\text {brine }}$ is not measured, it is determined by dividing the measured bulk salinity by $V_{\mathrm{b}}$, so that Eq. (4) becomes:

$R[x]_{\text {brine }}=[x]_{\text {measured }} \cdot S_{\text {ref }} / S_{\text {bulk }}$

In this way, concentration or dilution effects within and between cores have been fully accounted for, so that any variation between and within cores, and any difference between

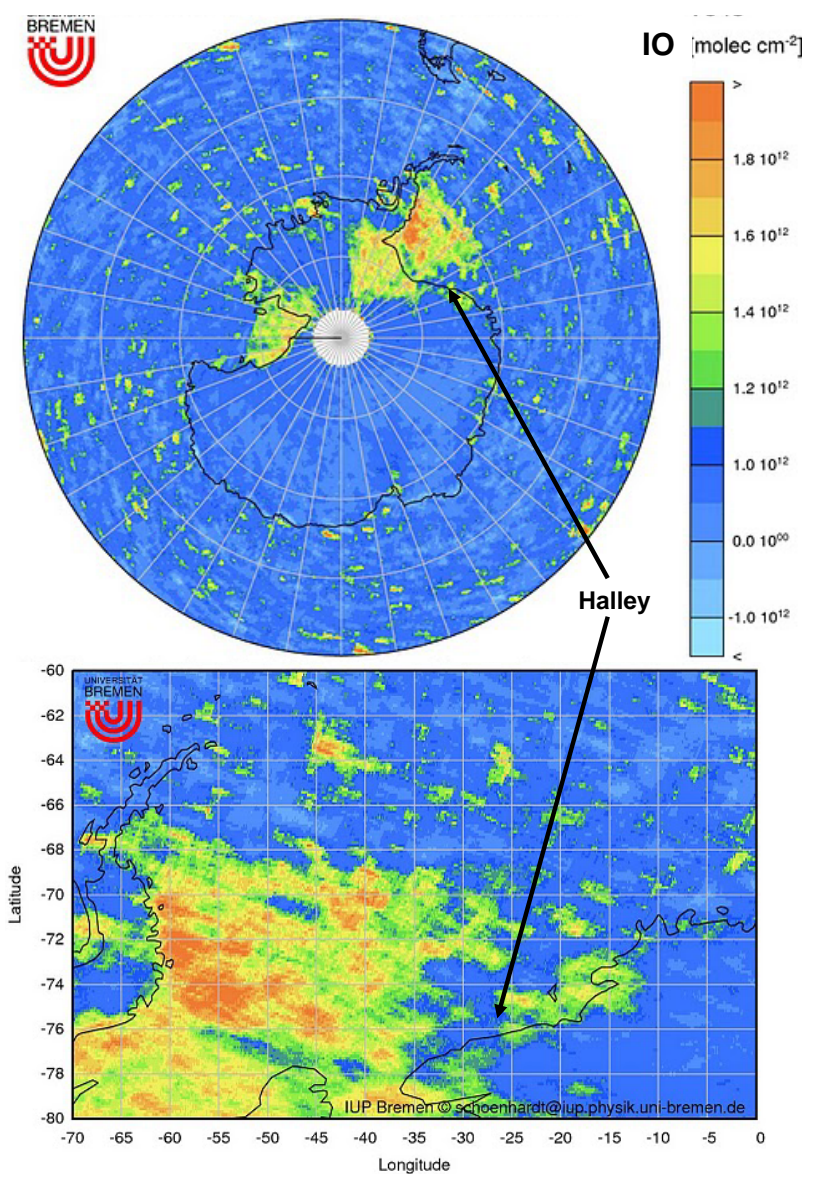

Fig. 5. Average IO vertical column densities over Antarctica measured by satellite from 25 January to 7 March 2009. The highest amounts of IO are observed over the ice covered Weddell Sea.

sea water and sea ice, is due solely to chemical and biological processes in the ice.

Original values of $[x]_{\text {measured }}$ are important for comparison with LoD in Table 2 . As the Sbulk was typically between 2 and $10 \%$, these measured values were typically 3 to 15 times smaller than the salinity rationalised values quoted. 


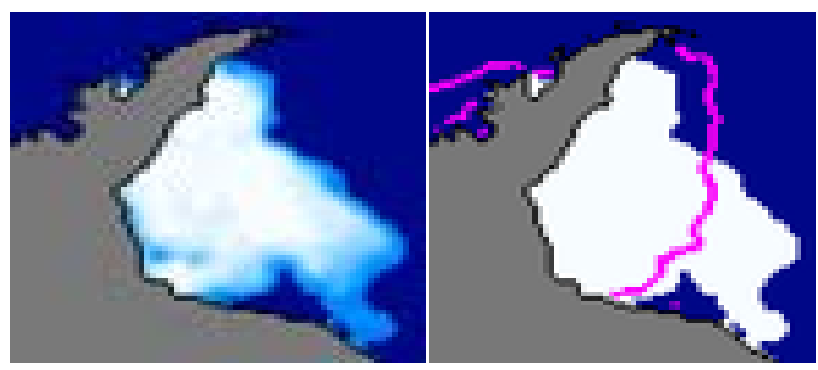

Fig. 6. Average ice coverage (left) and extent (right) for February 2009 , together with the median ice edge (pink line). Courtesy NSIDC.

An overview of halocarbon concentrations across all samples (water, air, ice) is given in Table 2. Halocarbon profiles from the 2 ice cores with $\mathrm{Chl} a$ data are shown in Fig. 7. Chl $a$ data is only available for a limited number of samples - two ice cores, each comprising 8 discrete sections, contained between 0.1 and $101 \mu \mathrm{g} \mathrm{L}^{-1} \mathrm{Chl} a$. Results, also salinity rationalised, are shown with halocarbon concentrations in Fig. 7. Note that the core of 13 February had much larger Chl $a$ than the core of 5 February. The presence of diatoms in the ice was confirmed via microscopy, small pennate diatoms dominated the community. Chl $a$ concentrations in 3 samples of DRI were 11,32 and $6.6 \mu \mathrm{g} \mathrm{L}-1$, much higher than that of the underlying seawater, where $\mathrm{Chl} a$ concentrations ranged from 0.05 to $0.22 \mu \mathrm{g} \mathrm{L}-1$ (average $0.14 \mu \mathrm{g} \mathrm{L}^{-1}$ ) across 4 samples. Typical Chl $a$ concentrations in Southern Ocean open waters range from 0.05 to $1.5 \mu \mathrm{g} \mathrm{L}^{-1}$ (Arrigo et al., 1998; El-Sayed, 2005) but values of up to $170 \mu \mathrm{g} \mathrm{L}^{-1}$ were reported during a plankton bloom in the Weddell sea (El-Sayed, 1971). In Antarctic sea ice the Chl $a$ concentration is normally less than $10 \mu \mathrm{g} \mathrm{L}^{-1}$ (Horner et al., 1992) but diatoms can lead to concentrations above $100 \mu \mathrm{g} \mathrm{L}^{-1}$ (Garrison et al., 2003).

The core of 5 February shows a peak in mono-iodocarbon concentrations close to the surface of the ice and a similar profile is seen for $\mathrm{CHBr}_{2} \mathrm{Cl}$. $\mathrm{CHBr}_{3}$ and $\mathrm{CH}_{2} \mathrm{ICl}$ concentrations show a similar profile to each other, with enhanced concentrations from $60-70 \mathrm{~cm}$, and $\mathrm{CH}_{2} \mathrm{Br}_{2}$ concentrations peak at both of these depths. A peak in $\mathrm{Chl} a$ is seen close to the surface of the ice, and a much larger peak at $50-60 \mathrm{~cm}$ depth.

The core of 13 February shows an enhancement in most compounds close to the surface. This core was collected in a different way to the others - a small boat was used to gain access to an ice floe where a near-surface diatom band was visible from the side. Despite enhanced iodocarbon concentrations there, the $\mathrm{Chl} a$ was not enhanced. This suggests either that the diatoms had died, or that horizontal migration of brine through the ice from its edge to the area sampled may have occurred (brine volume in this core ranged from 7 to $15 \%$, well above the percolation threshold for brine migration, Golden et al., 1998), or that the iodocarbons were not biogenic in origin. Note that different algal species will dom-
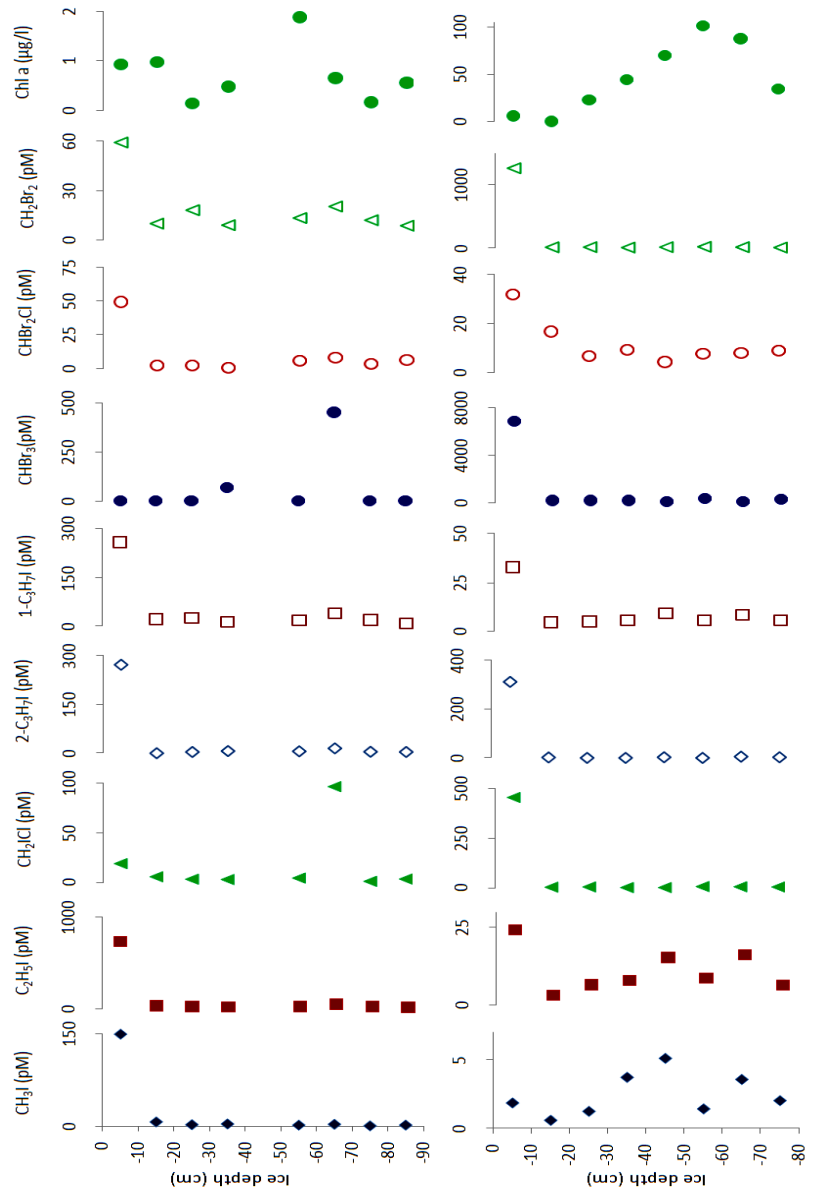

Fig. 7. Vertical profiles of Chl $a$ and halocarbons in sea ice on 5 February (left panel) and 13 February (right panel). Values have been normalised to brine volume and salinity rationalised as described in text. $\mathrm{CH}_{2} \mathrm{IBr}$ concentrations were $406 \mathrm{pM}$ in the top section of the core of 13 February and below the LoD in all other samples. Note the change in scale. The core of 13 February had a diatom band about $5 \mathrm{~cm}$ below the surface, similar to that of Fig. 2 .

inate throughout the ice thickness, each containing different amounts of $\mathrm{Chl} a$, so a comparison of the vertical profiles must be undertaken with caution.

Concentrations of halocarbons measured in USW samples are shown with atmospheric mixing ratios in Fig. 8. Most concentrations decreased as the summer progressed. Note that the ship was moving through variable ice cover rather than decreasing ice cover - even on days with periods of $8 / 10$ or more sea ice, there were alternating periods of 1/10.

Halocarbons were universally enhanced in sea ice relative to the underlying water (Table 2 and Fig. S1). MannWhitney statistical analysis showed that there is no statistical difference between the concentrations of any of the iodocarbons in ice and in DRI (p-values 0.32 to 0.49 ), but both ice and DRI contain much more iodocarbon than water ( $\mathrm{p}$ values $<0.0001$ to 0.0044 ). 


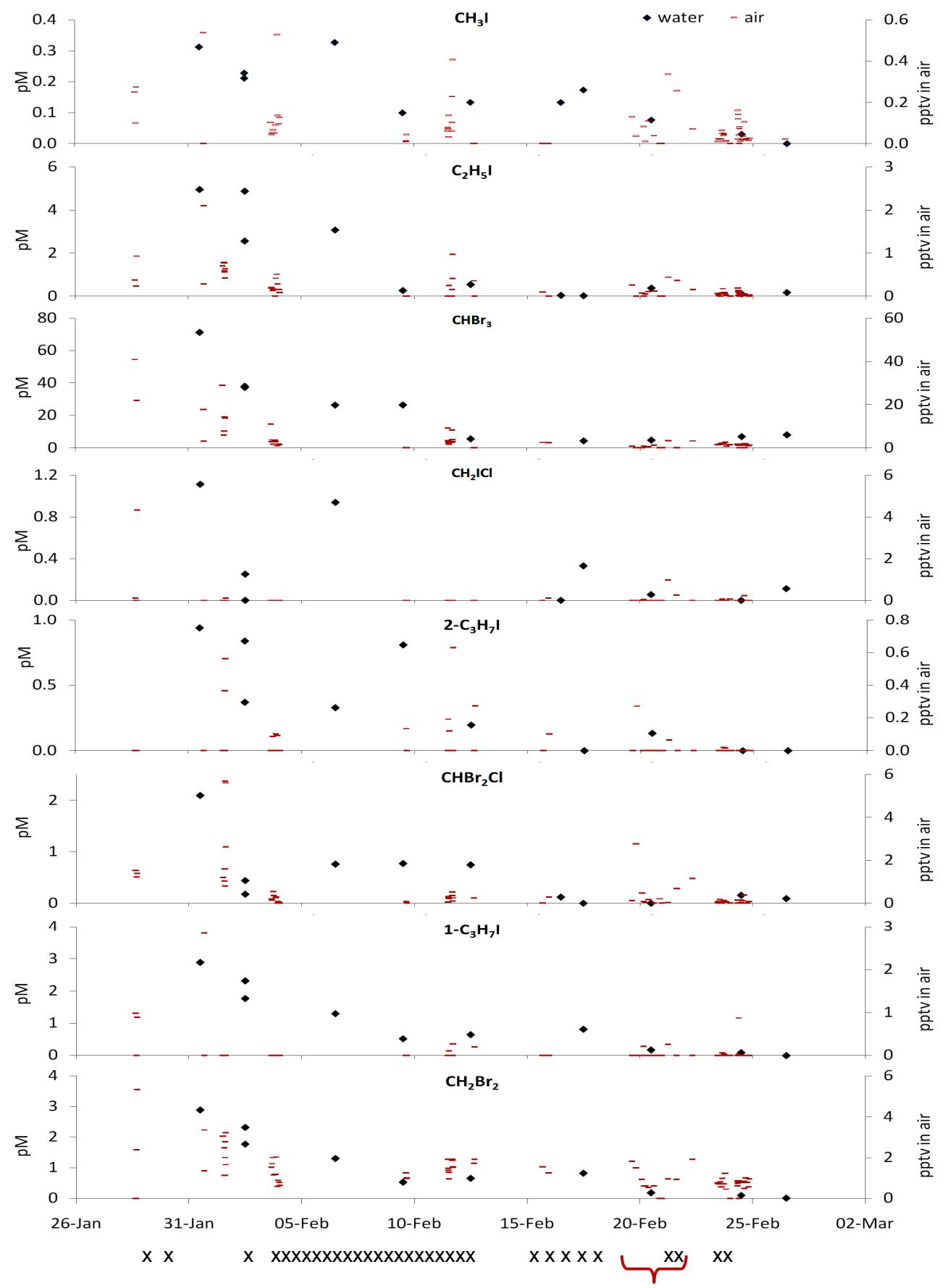

Fig. 8. Halocarbon concentrations in sea water samples (black diamonds), taken from the ship's USW supply, and mixing ratios in air (red lines). $\mathrm{CH}_{2} \mathrm{IBr}$ was not present above the $\mathrm{LoD}$. Air samples were taken from the Brunt Ice Shelf during the period denoted by the red downward-pointing bracket, black crosses indicate periods when sea ice varied between 1/10 and 10/10 around the ship.

The brine volume of the ice taken from ice cores ranged from 1.8 to $28 \%$ (average $11.8 \%$ ) and from diatom-rich ice samples from 19 to $29 \%$ (average $25 \%$ ). Brine volumes of the cores of Fig. 7 are listed in Table 4. The core of 5 February, where only the first $1 \mathrm{~m}$ of much thicker ice could be retrieved due to a temporary problem with the corer, was the only core where brine volume was less than $5 \%$, the threshold at which the brine channels close off to form isolated pockets at $-5^{\circ} \mathrm{C}$ (Golden et al., 1998). 


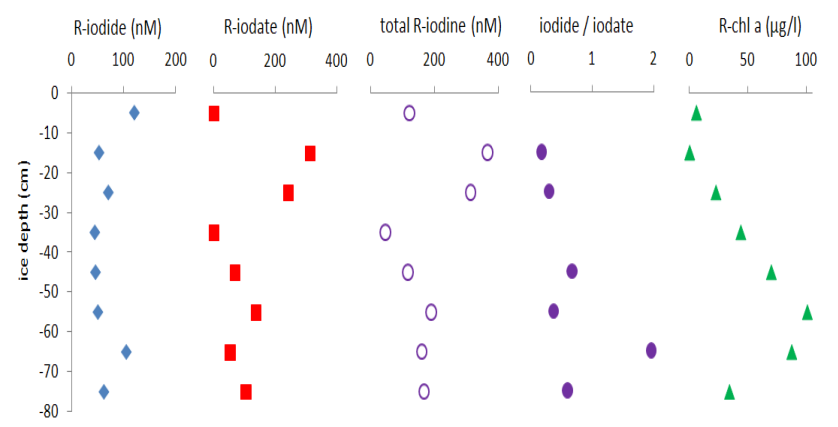

Fig. 9. Iodide, iodate and $\mathrm{Chl} a$ concentrations in the ice core of 13 March. Values have been normalised to brine volume and rationalised to salinity. Total iodine (iodide + iodate) and iodide/iodate ratios are also shown, except for the near-surface ratio where iodate was close to zero.

\subsection{Iodide and iodate}

Selected samples were analysed for iodide and iodate concentrations: one ice core (13 February, Fig. 9) comprising 8 samples at various depths, plus four DRI and a sample of underlying seawater (Table 3, plus Table S4 for more details). In seawater, the iodide concentration was $25 \pm 3 \mathrm{nM}$ and the iodate concentration was $364 \pm 10 \mathrm{nM}$ - similar to those observed previously in the Weddell Sea (Bluhm et al., 2011). In the ice core (normalised for brine volume and salinity, see Sect. 3.3), iodate concentrations at 15 and $25 \mathrm{~cm}$ depth were similar to those in the seawater, but substantially depleted elsewhere with no clear pattern with depth. Iodide concentrations were similar to the underlying seawater, with some enhancement at the surface and at $65 \mathrm{~cm}$ depth. The iodide distribution hints at a $\mathrm{C}$-shaped profile, which has been previously observed for compounds produced by diatoms in Southern Ocean sea ice, where biological activity is greatest near the surface and the base of the ice (Thomas and Dieckmann, 2002). The ratio of iodide to iodate provides some evidence for conversion of iodate to iodide, particularly towards the bottom of the ice core where $\mathrm{Chl} a$ levels are highest. This is consistent with biologically mediated reduction of iodate to iodide, as previously observed in diatom cultures (Chance et al., 2007; Bluhm et al., 2010).

At all ice-core depths except 15 and $25 \mathrm{~cm}$, total iodide plus iodate is depleted by $50 \%$ or more relative to the underlying seawater, indicating a missing iodine reservoir comparable to that identified in diatom culture experiments (Chance et al., 2007; Bluhm et al., 2010). This missing iodine could be in the particulate or non-volatile organic phase, or it could have been lost from the brine as a volatile organic or inorganic species. In the DRI, inorganic iodine depletion was even more pronounced, with iodide concentrations of $19 \pm 10 \mathrm{nM}$ in one sample and below the limit of detection in the others, and iodate concentrations below the limit of detection in all samples. Such a large loss of iodate has been
Table 4. Brine volumes in the cores of Fig. 7.

\begin{tabular}{lcc}
\hline $\begin{array}{l}\text { Date } \\
\text { Depth }(\mathrm{cm})\end{array}$ & $\begin{array}{c}\text { 5 February } \\
\text { Brine volume }(\%)\end{array}$ & $\begin{array}{c}\text { 13 February } \\
\text { Brine volume }(\%)\end{array}$ \\
\hline 5 & 0.3 & 9.3 \\
15 & 1.8 & 7.0 \\
25 & 5.0 & 9.7 \\
35 & 7.9 & 11.2 \\
55 & 3.6 & 14.8 \\
45 & - & 8.8 \\
65 & 3.4 & 9.2 \\
75 & 5.0 & 11.6 \\
85 & 6.6 & - \\
\hline
\end{tabular}

previously observed in incubations of marine aggregate material (Hughes et al., 2012). Such severe depletion implies a very active iodine chemistry within the sea-ice, about which very little is known. It is tempting to speculate that such active iodine cycling might also lead to significant volatilisation of iodine from the ice.

Both iodocarbons and iodide/iodate ratio are thought to be enhanced by biological activity. Despite Chl $a$ being a poor indicator of the abundance of species which have an active iodine metabolism, it is interesting that both $\mathrm{Chl} a$ and the iodide/iodate ratio are enhanced in the same area of the core in which both were measured. The enhancement in halocarbons close to the surface of the ice may be halocarbon production by surface diatom communities as discussed previously, or photochemical production, or by a reaction of $\mathrm{I}_{2}$ with organics. Diatoms can occur at gap layers near the surface (Fig. 2) as well as near the base. As any influence on the iodide/iodate ratio or halocarbon production will be species dependent, it is probably not surprising that they do not peak simultaneously, as different species will be present at different levels in the ice.

\subsection{Particles}

A previous field campaign in the Weddell Sea along a similar path found increased new particle formation in the sea ice zone of the Weddell Sea (Davison et al., 1996), but no clear correlation to the dimethyl sulphide that was then assumed to control new particle bursts.

During the current campaign, after removal of periods of possible contamination from the ship's smoke, open aerosol size spectra, where smaller size bins contains larger counts, were observed on nine days. Open spectra are strongly suggestive of new particle formation at a diameter smaller than the $9 \mathrm{~nm}$ minimum observed by our DMA system, followed by growth to larger diameters. In general, the open spectra were observed as the ship moved through sea ice. Figure 10 shows an example from 13 February, where particles grow into the range $>9 \mathrm{~nm}$ at $23: 30$, followed by growth over $30 \mathrm{~min}$ to size 20 to $30 \mathrm{~nm}$ as expected from condensation 


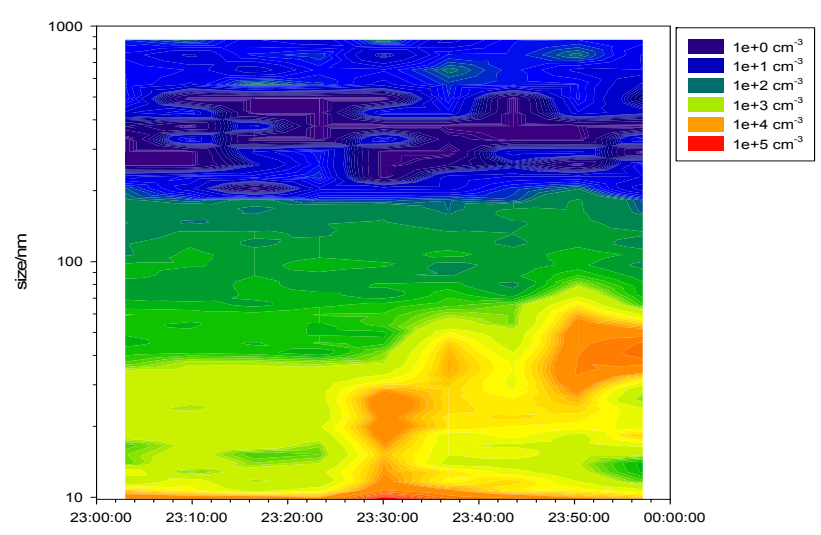

Fig. 10. Particle number size distribution $\left(\mathrm{cm}^{-3}\right)$, showing particle growth on 13 February 2009, probably from new particles formed as the ship broke through the sea ice of the Weddell Sea.

and coagulation. Before and after 23:30 the spectra had closed features, with smaller concentrations at $15 \mathrm{~nm}$ than $25 \mathrm{~nm}$, and at 23:30 there was a 10-fold increase in particles at $9.8 \mathrm{~nm}$. Hence we speculate that new particle formation occurred then at smaller diameters, and the evolution in the spectra in Fig. 10 shows their growth.

Some other examples are shown in Fig. S2, which also illustrate typical background and smoke-contaminated data. A comprehensive description and analysis of all the particle data must await a future publication.

\subsection{Air sampling on the Brunt Ice Shelf}

Average mixing ratios in air of $\mathrm{CH}_{3} \mathrm{I}, \mathrm{C}_{2} \mathrm{H}_{5} \mathrm{I}, \mathrm{CHBr}_{3}$, $\mathrm{CH}_{2} \mathrm{ICl}, \mathrm{CHBr}_{2} \mathrm{Cl}$, and $\mathrm{CH}_{2} \mathrm{Br}_{2}$ were $0.09,0.13,0.89,0.11$, 0.48 , and 0.87 pptv respectively (see Fig. 8) - broadly similar to those observed over the sea ice. 1- and $2-\mathrm{C}_{3} \mathrm{H}_{7} \mathrm{I}$ were only observed above the limit of detection twice during this period (at $<0.3 \mathrm{pptv}$ ), and $\mathrm{CH}_{2} \mathrm{IBr}$ only once (at $0.06 \mathrm{pptv}$ ). Figure 11 shows AIC was about 2 pptv, and $\mathrm{I}_{2}$ concentrations remained constant at about 8 pptv with the exception of the measurement of $31 \mathrm{pptv}$ on 20 February. Note that there is no lengthy night-time at this date at Halley, only a period of twilight, centred at about 02:00 GMT when the sun is just below the horizon. Local noon is at about 14:00 GMT whereas the measurement of $31 \mathrm{pptv}$ was at about 10:00 GMT, so this large amount of $I_{2}$ was not associated with diurnal variation.

Comparison of $I_{2}$ and iodocarbon mixing ratios to wind direction (Fig. 11) shows a maximum in $\mathrm{I}_{2}$ soon after the wind veered across the south-west, and a maximum in iodocarbon during and after the wind veered back again across the southwest, thereafter remaining enhanced. It is also possible that simultaneous maxima during these periods of veering winds were missed, as halocarbon samples were taken for $10 \mathrm{~min}$ once every $3 \mathrm{~h}$, whereas $\mathrm{I}_{2}$ samples were near-continuous for consecutive $3 \mathrm{~h}$ periods. Figure 1 shows that the ice edge extended north and south of the Brunt Ice Shelf. As the life-

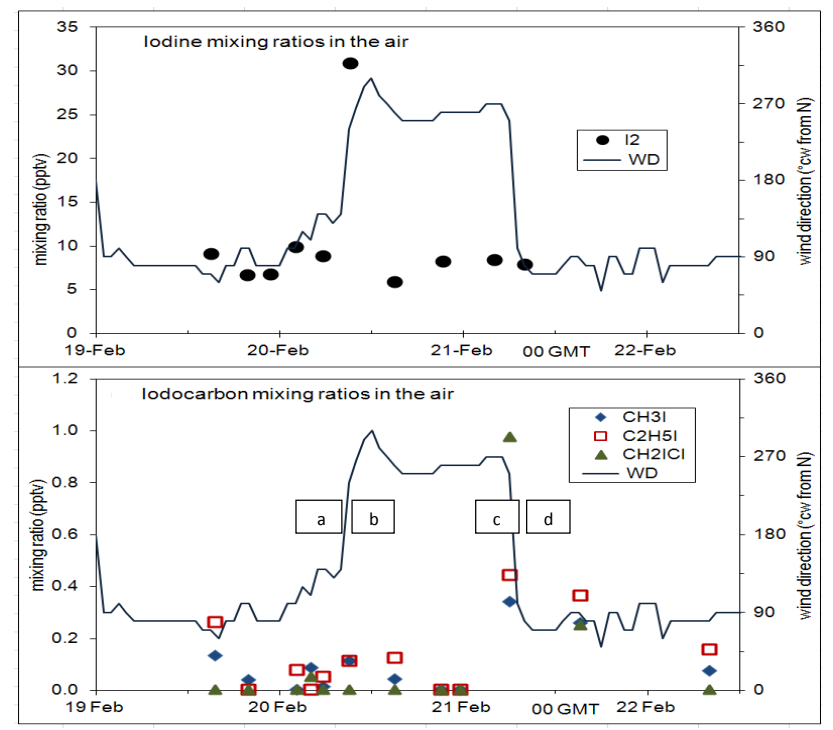

Fig. 11. Atmospheric $I_{2}$ (top panel) and iodocarbon (bottom panel) concentrations with corresponding wind direction. Ozone concentration was between 20 and 25 ppbv throughout the period. Back trajectories ending at the times of the letters are shown in Fig. 12. Back trajectories for the $12 \mathrm{~h}$ previous to (a) and (c) were from similar directions to those of (a) and (c).

time of $I_{2}$ is a few seconds at noon, the source had to be extremely close - in the ice edge or the snow. Back trajectories (Fig. 12) agree with the wind direction data (Fig. 11). There are no pulses in ozone that would cause a burst in $\mathrm{I}_{2}$ due to an increase in reaction of iodide with ozone in seawater, rather short ozone depletion events are seen as would be expected from such high concentrations of atmospheric iodine. The different time resolutions of ozone and inorganic iodine measurements, as well as the distance between sampling locations (the ozone monitor was on the ship), makes it difficult to determine the influence of inorganic iodine on ozone.

Halocarbon concentrations in interstitial air in the snow are shown in Fig. 13. $\mathrm{CH}_{3} \mathrm{I}$ and $\mathrm{C}_{2} \mathrm{H}_{5} \mathrm{I}$ had a diurnal profile with values of up to 0.5 and 1 pptv respectively - enhanced relative to those in air above. This suggests the snow is a source of these compounds, and the higher concentrations at night are due to the lower solar flux extending their lifetimes. These measurements are in good agreement with those of Swanson et al. (2007), who measured enhanced concentrations of $\mathrm{CH}_{3} \mathrm{I}$ and $\mathrm{C}_{2} \mathrm{H}_{5} \mathrm{I}$ in air in the snow at South Pole compared to the atmosphere above. Bromocarbon concentrations are similar in air in the snow to the air above, and concentrations of other halocarbons were below the detection limit. 


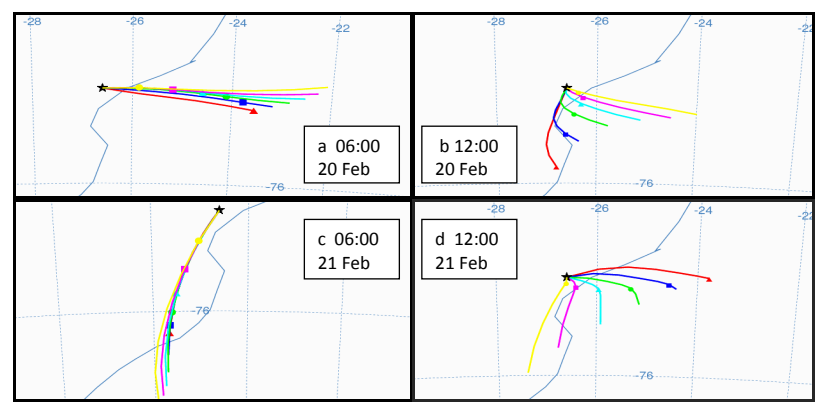

Fig. 12. 6-h back trajectories calculated by Hysplit (NOAA, 2010) for air masses reaching the air sampling site on the Brunt Ice Shelf in 2009. Trajectories arrived at the time in each chart letter (red), 1 $\mathrm{h}$ previously (blue), $2 \mathrm{~h}$ (green), $3 \mathrm{~h}$ (turquoise), $4 \mathrm{~h}$ (purple), and 5 $\mathrm{h}$ (yellow).

\subsection{Saturation anomalies and flux calculations}

Saturation anomalies are given in Table S5 and calculated fluxes in Table S6. Average and range of fluxes were 0.6 ( -0.1 to 3.8$), 1.5$ ( -0.1 to 2.8$),-1.3$ ( -15 to 2.9 ), 0.7 ( -0.1 to 4.8 ) and 1.0 (0 to 3.8) nmol m${ }^{-2}$ day $^{-1}$ for $\mathrm{CH}_{3} \mathrm{I}$, $\mathrm{C}_{2} \mathrm{H}_{5} \mathrm{I}, \mathrm{CH}_{2} \mathrm{ICl}, 2-\mathrm{C}_{3} \mathrm{H}_{7} \mathrm{I}$ and $1-\mathrm{C}_{3} \mathrm{H}_{7} \mathrm{I}$ respectively. $\mathrm{CH}_{2} \mathrm{IBr}$ concentrations were below detection limit in most air and water samples. Average and range of bromocarbon fluxes were -6.6 ( -130 to 110$),-5.4$ ( -62 to 4.6$)$ and $-4.2(-39$ to 13) nmol m${ }^{-2}$ day ${ }^{-1}$ for $\mathrm{CHBr}_{3}, \mathrm{CHBr}_{2} \mathrm{Cl}$ and $\mathrm{CH}_{2} \mathrm{Br}_{2}$ respectively. A negative flux represents a flux from atmosphere to sea. The predominant trend is for iodocarbons to be released from the sea and bromocarbons to be deposited.

Flux calculations were also carried out from halocarbon concentrations in the uppermost sections of ice cores or from diatom rich ice. As the ice contained such a large proportion of brine, the brine in the channels will replenish a layer of brine on the surface of the ice which will be in contact with the atmosphere. Halocarbon concentrations in the brine can therefore be treated as effective aqueous phase concentrations, and the usual empirical expressions (e.g. Nightingale et al., 2000) can be used to calculate brine - atmosphere fluxes. This is a method for calculating sea - air fluxes in open water, which aims to arrive at a first-order estimate, recognizing that the exchange between brine-skim and atmosphere might be much smaller than such open-water exchange.

Total iodine atom flux to the atmosphere was also calculated, assuming steady state concentrations for atmospheric halocarbons, so that the sum of halocarbon fluxes from ice and water is equal to the iodine atom flux to the atmosphere. As can be seen from Fig. 14, there is potential for sea ice brine to provide a very much larger flux of iodine to the atmosphere.

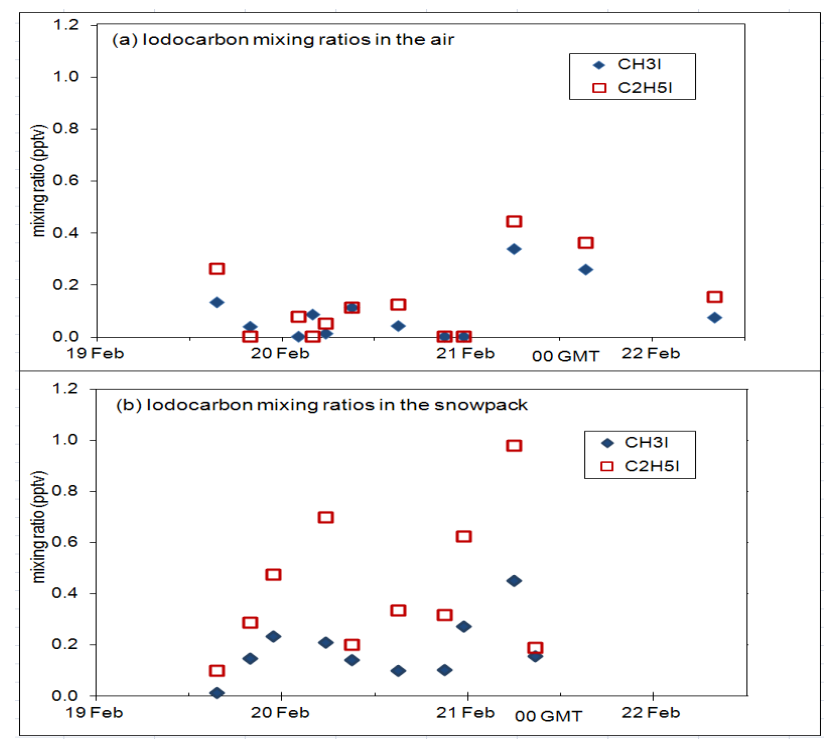

Fig. 13. Iodocarbon concentrations measured (a) in overlying air and (b) by drawing air through a Teflon-lined tube pushed $20 \mathrm{~cm}$ into the snowpack, on the Brunt Ice Shelf.

\subsection{Modelling results - contribution of reactive iodine species to IO budget}

Photolysis rates $\left(\mathrm{s}^{-1}\right)$ calculated for the location of Halley at noon in February (Z. Buys, personal communication, 2012) are $0.85,1.2 \times 10^{-2}, 4 \times 10^{-7}, 4 \times 10^{-7}, 1.3 \times 10^{-6}$, $1.2 \times 10^{-5}, 8 \times 10^{-4}$ for $\mathrm{I}_{2}, \mathrm{ICl}, \mathrm{CH}_{3} \mathrm{I}, \mathrm{C}_{2} \mathrm{H}_{5} \mathrm{I}, \mathrm{C}_{3} \mathrm{H}_{7} \mathrm{I}$, and $\mathrm{CH}_{2} \mathrm{I}_{2}$ respectively. The respective lifetimes are then $1.2 \mathrm{~s}$, $82 \mathrm{~s}, 29$ days, 29 days, 9 days, $22 \mathrm{~h}$ and 20 min respectively. The resultant iodine atoms then react with ozone to form IO. Photolysis of IO to I is rapid $\left(0.2 \mathrm{~s}^{-1}\right)$, so continuous recycling occurs between IO and I.

The THAMO model was run to answer the following questions:

a. What concentrations of IO result from the halocarbon fluxes in Sect. 3.7?

b. What atmospheric mixing ratios of $\mathrm{I}_{2}$ would be necessary to reproduce the measured vertical column of IO $\left(2.5 \times 10^{12}\right.$ molec $\left.\mathrm{cm}^{-2}\right)$, which if evenly distributed over $200 \mathrm{~m}$ would be 5 pptv of IO?

As $\mathrm{CH}_{2} \mathrm{I}_{2}$ was not measured during this field campaign, the $\mathrm{CH}_{2} \mathrm{I}_{2}$ flux previously measured close to Southern Ocean sea ice by a similar technique was used (Carpenter et al., 2007). $\mathrm{CH}_{2} \mathrm{I}_{2}$ is the most labile of the halocarbons, being photolysed in about $20 \mathrm{~min}$ at this latitude at noon, and thus will potentially contribute substantially to the iodine atom flux.

With THAMO, the maximum IO concentration resulting from halocarbon fluxes alone was $0.035 \mathrm{pptv}$, much less than observed. Tuning THAMO to reproduce the observed vertical column of IO demands an $\mathrm{I}_{2}$ flux equivalent to $4 \times 10^{10}$ 


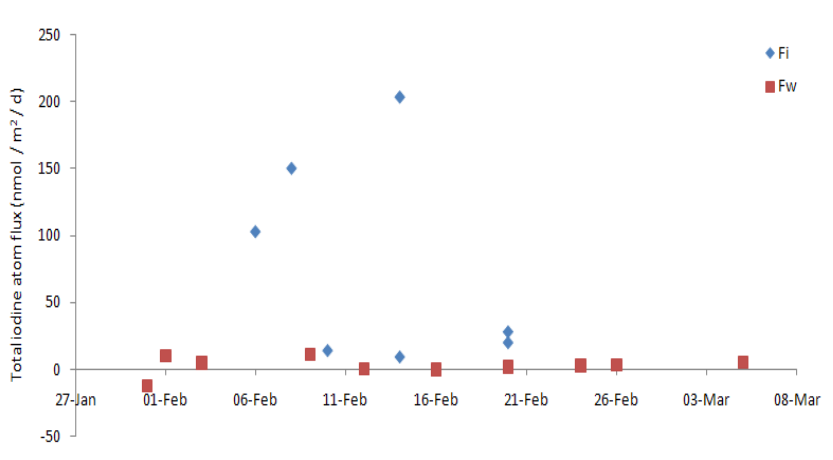

Fig. 14. Total iodine atom flux to the atmosphere, based on the sum of all fluxes of iodocarbons from ice, $F_{\mathrm{i}}$, and water, $F_{\mathrm{W}}$, assuming atmospheric halocarbon concentrations maintain a steady state.

atom $\mathrm{cm}^{-2} \mathrm{~s}^{-1}$, which is larger but of similar magnitude to previous flux estimates $\left(10^{9}\right.$ to $10^{10}$ atom $\mathrm{cm}^{-2} \mathrm{~s}^{-1}$ to account for IO and particle formation observed at Mace Head (McFiggans et al., 2004), $2 \times 10^{10}$ atom $\mathrm{cm}^{-2} \mathrm{~s}^{-1}$ to account for IO observed in Antarctica, Saiz-Lopez et al., 2008).

However, tuning THAMO to reproduce the mean observed $\mathrm{I}_{2}$ of $8.5 \mathrm{pptv}$ results in $170 \mathrm{pptv}$ of IO equally distributed over $200 \mathrm{~m}$, which is far larger than observed, whereas the new particles that result (Fig. 15) are only a little larger than those observed (Fig. 10 - note different colour scheme). Such discrepancies suggest an important gap in current understanding of atmospheric iodine chemistry.

\section{Discussion}

The measurements of iodine compounds shown here confirm the Weddell Sea as an iodine hotspot, as earlier suggested by Saiz-Lopez et al. (2007) and Schönhardt et al. (2008). A unique feature of this campaign was the simultaneous measurement of $\mathrm{I}_{2}$ and AIC in the sea ice zone, and observations of high concentrations of both (averaging 10 and $2 \mathrm{pptv}$ respectively). The mixing ratios of $I_{2}$ were similar to measurements in mid-latitude coastal locations, where macroalgae beds exposed at low tide are a known source of iodine: over 20 pptv of $I_{2}$ was observed during the day at Mace Head (Saiz-Lopez and Plane, 2004; Huang et al., 2010a). But this is the first time that such high $\mathrm{I}_{2}$ concentrations have been seen away from macroalgae beds.

The porosity of sea ice increases exponentially above $-5^{\circ} \mathrm{C}$ (Cox and Weeks, 1988). The average ice temperature during this campaign was $-1.8^{\circ} \mathrm{C}$. This ice has survived much of the melt season and brine has had chance to drain, therefore its salinity is low and its melting point is close to $0^{\circ} \mathrm{C}$. Thus, in the diatom-rich ice samples and most of the cores, the brine volume was such that the channels should be interconnected. Brine migration within the channels may then allow transport of dissolved ions and trace gases, pro-
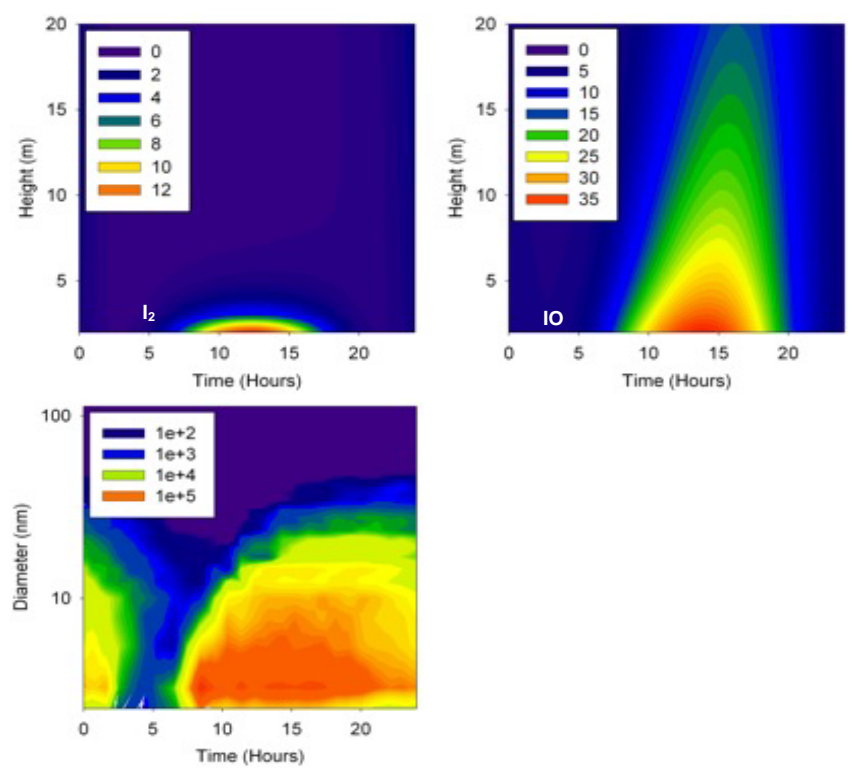

Fig. 15. THAMO model results after tuning the flux of $I_{2}$ above the measured halocarbon fluxes to reproduce measured $\mathrm{I}_{2}$ daytime near-surface mixing ratio of $8.5 \mathrm{pptv}$. Top left: vertical profile of $\mathrm{I}_{2}$. Top right: vertical profile of IO. Bottom left: spectrum of particle density $\mathrm{d} N / \mathrm{d} \log (\mathrm{d})\left(\mathrm{cm}^{-3}\right)$ at $10 \mathrm{~m}$.

viding a route from their sources in the ice to the atmosphere above.

Large amounts of atmospheric IO were also observed throughout the campaign, both from the ship and by satellite. By comparison, much smaller amounts of iodocarbons were observed in the atmosphere, with an average sum totalling only about $0.5 \mathrm{pptv}$. However, iodocarbons were strongly enhanced in the sea ice brine and DRI (average enhancement ratios between 12 and 48), suggesting a strong local source within the sea ice. In ice cores, iodocarbons mostly peaked close to the surface, consistent with much of the local biological activity (Fig. 2). These measurements were made in the warm summer with an average ice temperature of $-1.8^{\circ} \mathrm{C}$, at which brine channels would be interconnected so that the enhanced iodocarbons could certainly reach the atmosphere. However, flux calculations and model runs show that the resultant flux converted to iodine atoms is over 100 times too small to explain the observed amounts of IO.

What, then, is the mechanism of iodine release in the sea ice zone? Although production of halocarbons by diatoms has been shown to be connected to reduction of reactive oxygen species produced during cell metabolic processes (Collén et al., 1994), we have shown here that iodocarbons are in general unimportant - instead it is more likely that the mechanism involves $I_{2}$.

This is consistent with the abiotic mechanism proposed by O'Driscoll et al. (2006) from frozen sea water - see Introduction. It is also consistent with the suggestion by SaizLopez and Boxe (2008) that accumulation of $\mathrm{I}^{-}$by sea 
ice algae is followed by $\mathrm{I}_{2}$ release via the reaction $\mathrm{HOI}+$ $\mathrm{I}^{-}+\mathrm{H}^{+} \rightarrow \mathrm{I}_{2}+\mathrm{H}_{2} \mathrm{O}$. Although significant diffusion of halogenated compounds occurs via brine in channels (Loose et al., 2011; Shaw et al., 2011), the cold temperatures in spring when brine channels are often not connected would act to inhibit diffusion. Here we mostly sampled older more porous ice which had partially melted, so if the above suggestion were true, we could be seeing the end of a storage and release cycle. The high atmospheric levels of $\mathrm{I}_{2}$ and IO, the enhanced iodocarbon concentrations in the sea ice brine, the low total iodine in DRI, and the new particle formation when sailing through the ice, all support this hypothesis. The lack of downward flushing or upward volatilisation in spring would also support this hypothesis, unless the iodine were converted to an unreactive form.

But if the source of the $I_{2}$ is the sea ice, then huge amounts would need to be emitted at the sea ice surface for such high concentrations to be present at the height of the sampling tube on the ship $(10 \mathrm{~m})$ because of the short photolytic lifetime of $I_{2}$. This suggests a missing iodine component, also suggested by the very large depletion of iodide + iodate from the brine within the sea ice.

Finally, measurements on the Brunt Ice Shelf also showed that the dominant source of atmospheric iodine that we could observe was $\mathrm{I}_{2}$. There were large enhancements of both iodocarbons and $\mathrm{I}_{2}$ when trajectories had crossed the sea ice zone to the south-west, with $\mathrm{I}_{2}$ reaching $31 \mathrm{pptv}$ in one sample. Such large amounts above continental snow suggest that the snowpack may release reactive iodine, as proposed by Frieß et al. (2010), or via aerosol deposition and recycling as proposed by Saiz-Lopez et al. (2008). However, the source strength would have to be larger than ever recorded, suggesting recycling mechanisms that are not understood. An alternative could lie in the different type of sea ice (platelet) close to ice shelves, characterised by rapid nutrient exchange and high Chl $a$ concentrations (Bunt and Lee, 1970), which might give rise to different ice algal species (Bunt, 1964; Palmisano and Sullivan, 1985).

\section{Conclusions}

Our measurements confirmed that the Weddell Sea is an iodine hotspot, with large amounts of IO being observed in line with earlier studies (Saiz-Lopez et al., 2007; Schönhardt et al., 2008). For the first time, $I_{2}$ and AIC were observed above sea ice of the Weddell Sea and the nearby ice shelf, and the large concentrations of $\mathrm{I}_{2}$ were comparable to midlatitude measurements near macroalgae beds exposed at low tide (Saiz-Lopez and Plane, 2004; Huang et al., 2010a).

Observed concentrations of iodocarbons were much less, and although there is evidence for sea-ice and snow-pack sources of iodocarbons, the calculated fluxes are far too small to explain the observed atmospheric IO. Although modelled concentrations of reactive iodine consistent with the observed IO gives rise to modelled particle formation that agrees well with the observed new particles, the modelled $\mathrm{I}_{2}$ is far smaller than the observed $\mathrm{I}_{2}$. Together with the large depletion in iodide + iodate observed in the sea ice brine, this suggests there is an unidentified iodine source, presumably inorganic, or there are major gaps in our understanding of iodine chemistry.

\section{Supplementary material related to this article is available online at: http://www.atmos-chem-phys.net/12/ 11229/2012/acp-12-11229-2012-supplement.pdf.}

Acknowledgements. We wish to thank Ted Maksym (BAS) for loan of the ice corer, Anna Jones (BAS) for use of the MAXDOAS, Neil Brough (BAS) for major help with the preparation of the MAX-DOAS, Claire Allen (BAS) for advice on diatoms, Stephane Bauguitte (BAS) for preparing the denuder pumping system, Martin Johnson (UEA) for help with maths, Keith Nicholls and supporting scientists and crew on the RRS Ernest Shackleton, Mike Dinn (BAS) for setting up the cruise opportunity, Francois Hendrick (BIRA) for supply of air mass factors, and Michel Van Roozendael of BIRA for WinDOAS software. HKR's participation is part of the British Antarctic Survey's Polar Science for Planet Earth programme, funded by NERC. HMA acknowledges NERC for a studentship.

Edited by: L. Ganzeveld

\section{References}

Ackley, S. F., Lewis, M. J., Fritsen, C. H., and Xie, H.: Internal melting in Antarctic sea ice: Development of "gap layers", Geophys. Res. Lett., 35, L11503, doi:10.1029/2008GL033644, 2008.

Allen, A. G., Grenfell, J. L., Harrison, R. M., James, J., and Evans, M. J.: Nanoparticle formation in marine airmasses: contrasting behaviour of the open ocean and coastal environments, Atmos. Res., 51, 1-14, 1999.

Arrigo, K. R., Worthen, D. L., Dixon, P., and Lizotte, M. P.: Primary productivity of near surface communities within Antarctic pack ice, Antarctic Res. Ser., 73, 23-43, 1998.

Barrie, L. A., Bottenheim, J. W., Schnell, R. C., Crutzen, P. J., and Rasmussen, R. A.: Ozone destruction and photochemical reactions at polar sunrise in the lower Arctic atmosphere, Nature, 334, 138-141, 1988.

Bluhm, K., Croot, P., Wuttig, K., and Lochte, K.: Transformation of iodate to iodide in marine phytoplankton driven by cell senescence, Aquatic Biology, 11, 1-15, doi:10.3354/ab00284, 2010.

Bluhm, K., Croot, P., Huhn, O., Rohardt, G., and Lochte, K.: Distribution of iodide and iodate in the Atlantic sector of the southern ocean during austral summer, Deep-Sea Res. II, 58, 2733-2748, doi:10.1016/j.dsr2.2011.02.002, 2011.

Bunt, J. S.: Primary productivity under sea ice in Antarctic waters, Antarctic Res. Ser., 1, 13-31, 1964.

Bunt, J. and Lee, C.: Seasonal primary production in Antarctic sea ice at McMurdo Sound in 1967, J. Mar. Res., 28, 304-320, 1970. 
Carpenter, L. J., Sturges, W. T., Penkett, S., Liss, P., Alicke, B., Hebestreit, K., and Platt, U.: Short-lived alkyl iodides and bromides at Mace Head, Ireland- Links to biogenic sources and halogen oxide production, J. Geophys. Res., 104, 1679-1689, 1999.

Carpenter, L. J., Hopkins, J. R., Jones, C. E., Lewis, A. C., Parthipan, R., Wevill, D. J., Poissant, L., Pilote, M., and Constant, P.: Abiotic Source of $\mathrm{CH}_{2} \mathrm{I}_{2}$ and other reactive Organic Halogens in the Sub-Arctic Atmosphere?, Environ. Sci. Tech., 39, 8812-8816, 2005.

Carpenter, L. J., Wevill, D. J., Palmer, C. J., and Michels, J.: Depth profiles of volatile iodine and bromine-containing halocarbons in coastal Antarctic waters, Marine Chemistry, 103, 227-236, 2007.

Chameides, W. L. and Davis, D. D.: Iodine- Its possible role in tropospheric photochemistry, J. Geophys. Res., 85, 7383-7398, 1980.

Chance, R., Malin, G., Jickells, T., and Baker, A. R.: Reduction of iodate to iodide by cold water diatom cultures, Marine Chemistry, 105, 169-180, 2007.

Collén, J., Ekdahl, A., Abrahamsson, K., and Pedersén, M.: The involvement of hydrogen peroxide in the production of volatile halogenated compounds by Meristiella gelidium, Phytochemistry, 36, 1197-1202, 1994.

Cox, G. and Weeks, W. F.: Numerical Simulations of the Profile Properties of Undeformed First-Year Sea Ice During the Growth Season, J. Geophys. Res., 93, 12449-12460, 1988.

Davison, B., Hewitt, C. N., O’Dowd, C., Lowe, J. A., Smith, M. H., Schwikowski, M., Baltensperger, U., and Harrison, R. M.: Dimethyl sulfide, methane sulfonic acid and physicochemical aerosol properties in Atlantic air from the United Kingdom to Halley Bay, J. Geophys. Res., 101, 22855-22867, 1996.

de la Cuesta, J. and Manley, S. L.: Iodine assimilation by marine diatoms and other phytoplankton in nitrate-replete conditions, Limnol. Oceanogr., 54, 1653-1664, 2009.

El-Sayed, S. Z.: Observations on phytoplankton bloom in the Weddell Sea, Biology of the Antarctic Seas IV, 17, edited by: Llano, G. A. and Wallen, I. E., 301-312, 1971.

El-Sayed, S. Z.: History and evolution of primary productivity studies of the Southern Ocean, Polar Biol., 28, 423-438, 2005.

Fogelqvist, E. and Tanhua, T.: Iodinated C1-C4 hydrocarbons released from ice algae in Antarctic, Naturally Produced Organohalogens, edited by: Grimvall, A. and de Leer, E. W. B., Kluwer Academic Publishers, Dordrecht, The Nederlands, 295305, 1995.

Frankenstein, G. and Garner, R.: Equations for determining the brine volume of sea ice from- $0.5 \mathrm{C}$ to-22.9 C, J. Glaciol., 6, $943-$ 944, 1967

Frieß, U., Deutschmann, T., Gilfedder, B. S., Weller, R., and Platt, U.: Iodine monoxide in the Antarctic snowpack, Atmos. Chem. Phys., 10, 2439-2456, doi:10.5194/acp-10-2439-2010, 2010.

Furneaux, K. L., Whalley, L. K., Heard, D. E., Atkinson, H. M., Bloss, W. J., Flynn, M. J., Gallagher, M. W., Ingham, T., Kramer, L., Lee, J. D., Leigh, R., McFiggans, G. B., Mahajan, A. S., Monks, P. S., Oetjen, H., Plane, J. M. C., and Whitehead, J. D.: Measurements of iodine monoxide at a semi polluted coastal location, Atmos. Chem. Phys., 10, 3645-3663, doi:10.5194/acp10-3645-2010, 2010.

Garrison, D. L. and Buck, K. R.: The biota of Antarctic pack ice in the Weddell sea and Antarctic Peninsula regions, Polar Biol., 10, 211-219, 1989
Garrison, D. L., Jeffries, M. O., Gibson, A., Coale, S. L., Neenan, D., Fritsen, C., Okolodkov, Y. B., and Gowing, M. M.: Development of sea ice microbial communities during autumn ice formation in the Ross Sea, Mar. Ecol. Prog. Ser., 259, 1-15, 2003.

Golden, K., Ackley, S., and Lytle, V.: The percolation phase transition in sea ice, Science, 282, 2238-2241, 1998.

Haas, C., Thomas, D. N., and Bareiss, J.: Surface properties and processes of perennial Antarctic sea ice in summer, J. Glaciol., 47, 613-625, 2001.

Hill, V. L. and Manley, S. L.: Release of reactive bromine and iodine from diatoms and its possible role in halogen transfer in polar and tropical oceans, Limnol. Oceanogr., 54, 812-822, 2009.

Hönninger, G. and Platt, U.: Observations of $\mathrm{BrO}$ and its vertical distribution during surface ozone depletion at Alert, Atmos. Environ., 36, 2481-2489, 2002.

Hopkins, F. E., Kimmance, S. A., Stephens, J. A., Bellerby, R. G. J., Brussaard, C. P. D., Czerny, J., Schulz, K. G., and Archer, S. D.: Response of halocarbons to ocean acidification in the Arctic, Biogeosciences Discuss., 9, 8199-8239, doi:10.5194/bgd-98199-2012, 2012.

Horner, R., Ackley, S. F., Dieckmann, G. S., Gulliksen, B., Hoshiai, T., Legendre, L., Melnikov, I. A., Reeburgh, W. S., Spindler, M., and Sullivan, C. W.: Ecology of sea ice biota. I: Habitat, terminology, and methodology, Polar Biol., 12, 417-427, 1992.

Huang, R. J. and Hoffmann, T.: Development of a coupled diffusion denuder system combined with gas chromatography/mass spectrometry for the separation and quantification of molecular iodine and the activated iodine compounds iodine monochloride and hypoiodous acid in the marine atmosphere, Anal. Chem., 81, 1777-1783, 2009 .

Huang, R.-J., Seitz, K., Buxmann, J., Pöhler, D., Hornsby, K. E., Carpenter, L. J., Platt, U., and Hoffmann, T.: In situ measurements of molecular iodine in the marine boundary layer: the link to macroalgae and the implications for $\mathrm{O}_{3}, \mathrm{IO}, \mathrm{OIO}$ and $\mathrm{NO}_{\mathrm{x}}$, Atmos. Chem. Phys., 10, 4823-4833, doi:10.5194/acp-10-48232010, 2010a.

Huang, R. J., Seitz, K., Neary, T., O’Dowd, C. D., Platt, U., and Hoffmann, T.: Observations of high concentrations of $\mathrm{I}_{2}$ and IO in coastal air supporting iodine-oxide driven coastal new particle formation, Geophys. Res. Lett., 37, L03803, doi:10.1029/2009GL041467, 2010b.

Hughes, C., Chuck, A. L., Turner, S. M., and Liss, P. S.: Methyl and ethyl nitrate saturation anomalies in the Southern Ocean (36$\left.65^{\circ} \mathrm{S}, 30-70^{\circ} \mathrm{W}\right)$, Env. Chem., 5, 11-15, 2008.

Hughes, C., Kettle, A. J., Unazi, G. A., Weston, K., Jones, M. R., and Johnson, M. T.: Seasonal variations in the concentrations of methyl and ethyl nitrate in a shallow freshwater lake, Limnol. Oceanogr., 55, 305-314, 2010.

Jickells, T., Boyd, S., and Knap, A.: Iodine cycling in the Sargasso Sea and the Bermuda inshore waters, Marine Chemistry, 24, 6182,1988

Johnson, M. T.: A numerical scheme to calculate temperature and salinity dependent air-water transfer velocities for any gas, Ocean Sci., 6, 913-932, doi:10.5194/os-6-913-2010, 2010.

Kattner, G., Thomas, D. N., Haas, C., Kennedy, H., and Dieckmann, G.: Surface ice and gap layers in Antarctic sea ice: highly productive habitats, Ecol. Progr. Ser., 277, 1-12, 2004.

King, J. and Anderson, P.: Heat and water vapour fluxes and scalar roughness lengths over an Antarctic ice shelf, Bound.-Lay. Me- 
teor., 69, 101-121, 1994.

Loose, B., Schlosser, P., Perovich, D., Ringelberg, D., Ho, D., Takahashi, T., Richter-Menge, J., Reynolds, C., McGillis, W., and Tison, J. L.: Gas diffusion through columnar laboratory sea ice: implications for mixed layer ventilation of $\mathrm{CO}_{2}$ in the seasonal ice zone, Tellus B, 63, 23-39, 2011.

Luther, G. W., Swartz, C. B., and Ullman, W. J.: Direct determination of iodide in seawater by cathodic stripping square wave voltammetry, Anal. Chem., 60, 1721-1724, 1988.

Mahajan, A. S., Plane, J. M. C., Oetjen, H., Mendes, L., Saunders, R. W., Saiz-Lopez, A., Jones, C. E., Carpenter, L. J., and McFiggans, G. B.: Measurement and modelling of tropospheric reactive halogen species over the tropical Atlantic Ocean, Atmos. Chem. Phys., 10, 4611-4624, doi:10.5194/acp-10-4611-2010, 2010.

Mahajan, A. S., Sorribas, M., Gómez Martín, J. C., MacDonald, S. M., Gil, M., Plane, J. M. C., and Saiz-Lopez, A.: Concurrent observations of atomic iodine, molecular iodine and ultrafine particles in a coastal environment, Atmos. Chem. Phys., 11, 25452555, doi:10.5194/acp-11-2545-2011, 2011.

Martino, M., Mills, G. P., Woeltjen, J., and Liss, P. S.: A new source of volatile organoiodine compounds in surface seawater, Geophys. Res. Lett., 36, L01609, doi:10.1029/2008GL036334, 2009.

McFiggans, G., Coe, H., Burgess, R., Allan, J., Cubison, M., Alfarra, M. R., Saunders, R., Saiz-Lopez, A., Plane, J. M. C., Wevill, D., Carpenter, L., Rickard, A. R., and Monks, P. S.: Direct evidence for coastal iodine particles from Laminaria macroalgae - linkage to emissions of molecular iodine, Atmos. Chem. Phys., 4, 701-713, doi:10.5194/acp-4-701-2004, 2004.

Moore, R., Webb, M., Tokarczyk, R., and Wever, R.: Bromoperoxidase and iodoperoxidase enzymes and production of halogenated methanes in marine diatom cultures, J. Geophys. Res., 101, 20899-20908, 1996.

NOAA: http://ready.arl.noaa.gov/hysplit-bin/trajasrc.pl (last access: January 2012), 2010.

Nightingale, P. D., Malin, G., Law, C., Watson, A., Liss, P., Liddicoat, M., Boutin, J., and Upstill-Goddard, R.: In situ evaluation of air-sea gas exchange parameterisations using novel conservative and volatile tracers, Global Biogeochem. Cy., 14, 373-387, 2000.

O’Dowd, C. D., Jimenez, J. L., Bahreini, R., Flagan, R. C., Seinfeld, J. H., Hameri, K., Pirjola, L., Kulmala, M., Jennings, S. G., and Hoffmann, T.: Marine aerosol formation from biogenic iodine emissions, Nature, 417, 632-636, 2002.

O’Driscoll, P., Lang, K., Minogue, N., and Sodeau, J.: Freezing halide ion solutions and the release of interhalogens to the atmosphere, J. Phys. Chem. A, 110, 4615-4618, 2006.

Palmisano, A. and Sullivan, C. W.: Growth, metabolism, and dark survival in sea ice microalgae, Sea ice biota, edited by: Horner, R. A., CRC Press, Boca Raton, Florida, 131-146, 1985.
Renfrew, I. A. and King, J. C.: A Simple Model Of The Convective Internal Boundary Layer And Its Application To Surface Heat Flux Estimates Within Polynyas, Boundary-Lay. Meteor., 94, 335-356, 2000.

Saiz-Lopez, A. and Boxe, C. S.: A mechanism for biologicallyinduced iodine emissions from sea-ice, Atmos. Chem. Phys. Discuss., 8, 2953-2976, doi:10.5194/acpd-8-2953-2008, 2008.

Saiz-Lopez, A. and Plane, J. M. C.: Novel iodine chemistry in the marine boundary layer, Geophys. Res. Lett., 31, L04112, doi:10.1029/2003GL019215, 2004.

Saiz-Lopez, A., Mahajan, A. S., Salmon, R. A., Bauguitte, S. J. B., Jones, A. E., Roscoe, H. K., and Plane, J. M. C.: Boundary Layer Halogens in Coastal Antarctica, Science, 317, 348-351, 2007.

Saiz-Lopez, A., Plane, J. M. C., Mahajan, A. S., Anderson, P. S., Bauguitte, S. J.-B., Jones, A. E., Roscoe, H. K., Salmon, R. A., Bloss, W. J., Lee, J. D., and Heard, D. E.: On the vertical distribution of boundary layer halogens over coastal Antarctica: implications for $\mathrm{O}_{3}, \mathrm{HO}_{\mathrm{x}}, \mathrm{NO}_{\mathrm{x}}$ and the $\mathrm{Hg}$ lifetime, Atmos. Chem. Phys., 8, 887-900, doi:10.5194/acp-8-887-2008, 2008.

Sander, R.: Compilation of Henry's law constants for inorganic and organic species of potential importance in environmental chemistry, available at: http://www.henrys-law.org (last access: May 2011), 1999.

Schönhardt, A., Richter, A., Wittrock, F., Kirk, H., Oetjen, H., Roscoe, H. K., and Burrows, J. P.: Observations of iodine monoxide columns from satellite, Atmos. Chem. Phys., 8, 637-653, doi:10.5194/acp-8-637-2008, 2008.

Shaw, M. D., Carpenter, L. J., Baeza-Romero, M. T., and Jackson, A. V.: Thermal evolution of diffusive transport of atmospheric halocarbons through artificial sea-ice, Atmos. Environ., 45, 6393-6402, doi:10.1016/j.atmosenv.2011.08.023, 2011.

Slingo, A.: Sensitivity of the Earth's radiation budget to changes in low clouds, Nature, 343, 49-51, 1990.

Spokes, L. J. and Liss, P. S.: Photochemically induced redox reactions in seawater, II. Nitrogen and iodine, Marine Chemistry, 54, 1-10, 1996.

Swanson, A. L., Blake, N. J., Blake, D. R., Sherwood Rowland, F., Dibb, J. E., Lefer, B. L., and Atlas, E.: Are methyl halides produced on all ice surfaces? Observations from snow-laden field sites, Atmos. Environ., 41, 5162-5177, 2007.

Thomas, D. N. and Dieckmann, G. S.: Antarctic sea ice: A habitat for extremophiles, Science, 295, 641-644, 2002.

Tokarczyk, R. and Moore, R. M.: Production of volatile organohalogens by phytoplankton cultures, Geophys. Res. Lett., 21, 285288, 1994.

Vogt, R., Crutzen, P. J., and Sander, R.: A mechanism for halogen release from sea-salt aerosol in the remote marine boundary layer, Nature, 383, 327-330, 1996. 